OPEN ACCESS

Edited by:

Romuald Lipcius,

College of William \& Mary,

United States

Reviewed by:

Joanne Irene Ellis,

University of Waikato, New Zealand

Lorenzo Alvarez-Filip,

National Autonomous University

of Mexico, Mexico

*Correspondence:

Magdalena Précoma-de la Mora

mprecoma@cobi.org.mx

Nathan J. Bennett

nathan.j.bennett.1@gmail.com

${ }^{\dagger}$ These authors share first authorship

Specialty section:

This article was submitted to

Marine Conservation

and Sustainability,

a section of the journal

Frontiers in Marine Science

Received: 17 September 2021 Accepted: 12 November 2021

Published: 14 December 2021

Citation

Précoma-de la Mora $M$, Bennett NJ, Fulton S,

Munguia-Vega A, Lasch-Thaler $C$,

Walther-Mendoza $M$,

Zepeda-Domínguez JA,

Finkbeiner EM, Green AL, Suárez A, Weaver AH, Figueroa Carranza ALR,

Vega Velázquez $A$, Zepeda $C$

Montes C, Fuentes Montalvo DA, Micheli F, Reyes-Bonilla H, Chollett I,

Lopez-Ercilla I, Torres Origel JF,

Vázquez-Vera L, García-Rivas MC

Mancha-Cisneros MM

Espinosa-Romero MJ, Martín Ruíz M, Arafeh-Dalmau N,

González-Cuellar OT, Huchim O and

Rodríguez Van Dyck S (2021)

Integrating Biophysical,

Socio-Economic and Governance

Principles Into Marine Reserve Design and Management in Mexico: From

Theory to Practice.

Front. Mar. Sci. 8:778980.

doi: 10.3389/fmars.2021.778980

\section{Integrating Biophysical,} Socio-Economic and Governance Principles Into Marine Reserve Design and Management in Mexico:
From Theory to Practice

\author{
Magdalena Précoma-de la Mora ${ }^{1 * t}$, Nathan J. Bennett ${ }^{2 * t}$, Stuart Fulton ${ }^{1}$, \\ Adrian Munguia-Vega ${ }^{3}$, Cristina Lasch-Thaler ${ }^{4}$, Mariana Walther-Mendoza ${ }^{4}$, \\ José Alberto Zepeda-Domínguez ${ }^{5}$, Elena Marie Finkbeiner ${ }^{6}$, Alison L. Green ${ }^{7}$, \\ Alvin Suárez ${ }^{8}$, Amy Hudson Weaver ${ }^{9}$, Ana Luisa R. Figueroa Carranza ${ }^{10}$, \\ Armando Vega Velázquez ${ }^{11}$, Calina Zepeda ${ }^{4}$, Celerino Montes ${ }^{10}$, \\ David Antonio Fuentes Montalvo ${ }^{12}$, Fiorenza Micheli ${ }^{13}$, Héctor Reyes-Bonilla ${ }^{14}$, \\ Iliana Chollett ${ }^{15}$, Ines Lopez-Ercilla', Juan Francisco Torres Origel ${ }^{4}$, \\ Leonardo Vázquez-Vera ${ }^{4,14}$, María del Carmen García-Rivas ${ }^{10}$, \\ María del Mar Mancha-Cisneros ${ }^{16}$, María José Espinosa-Romero', Mirian Martín Ruíz ${ }^{17}$, \\ Nur Arafeh-Dalmau ${ }^{18}$, Ollin T. González-Cuellar ${ }^{19}$, Oswaldo Huchim ${ }^{20}$ and \\ Salvador Rodríguez Van Dyck ${ }^{19}$
}

${ }^{1}$ Comunidad y Biodiversidad, A.C., La Paz, Mexico, ${ }^{2}$ The Peopled Seas Initiative, Vancouver, BC, Canada, ${ }^{3}$ Desert Laboratory on Tumamoc Hill, University of Arizona, Tucson, AZ, United States, ${ }^{4}$ The Nature Conservancy, Mérida, Mexico, ${ }^{5}$ Facultad de Ciencias Marinas, Universidad Autónoma de Baja California, Ensenada, Mexico, ${ }^{6}$ Center for Oceans, Conservation International, Honolulu, HI, United States, ${ }^{7}$ Reef Ecology Lab, King Abdullah University of Science and Technology, Thuwal, Saudi Arabia, ${ }^{8}$ Centro de Estudios Biológicos, Medio Ambiente y Recursos Naturales, A.C., Felipe Carrillo Puerto, Mexico, ${ }^{9}$ Consultant, La Paz, Mexico, ${ }^{10}$ Comisión Nacional de Áreas Naturales Protegidas, Hermosillo, Mexico, ${ }^{11}$ Instituto Nacional de Pesca y Acuacultura, La Paz, Mexico, ${ }^{12}$ Consultant, Ciudad de México, Mexico, ${ }^{13}$ Hopkins Marine Station, Stanford University, Pacific Grove, CA, United States, ${ }^{14}$ Departamento Académico de Ciencias Marinas y Costeras, Universidad Autónoma de Baja California Sur, La Paz, Mexico, ${ }^{15}$ Sea Cottage, Louisburgh, Ireland, ${ }^{16}$ Coasts and Commons Co-laboratory, Duke University, Beaufort, NC, United States, ${ }^{17}$ Fundación Haciendas del Mundo Maya, A.C., Mérida, Mexico, ${ }^{18}$ Centre for Biodiversity and Conservation Science, The University of Queensland, Brisbane, QLD, Australia, ${ }^{19}$ Sociedad de Historia Natural Niparajá, A.C., La Paz, Mexico, ${ }^{20}$ Escuela de Ciencias de la Salud, Universidad Marista de Mérida, Mérida, Mexico

Marine conservation design and fisheries management are increasingly integrating biophysical, socio-economic and governance considerations. Integrative approaches are adopted to achieve more effective, equitable, inclusive, and robust marine policies and practices. This paper describes a participatory process to co-produce biophysical, socio-economic, and governance principles to guide the design and management of marine reserves in three regions of Mexico: the Pacific region of the Baja California Peninsula, the Gulf of California, and the Mexican Caribbean. The process of coproducing the principles included convening a coordination team, reviewing the science, convening multi-stakeholder workshops, developing and communicating the principles with key practitioners and policy makers, and supporting uptake and application to policy and practice. Biophysical principles were related to: habitat representation and risk spreading; protecting critical, special and unique areas; incorporating connectivity; allowing time for recovery; adapting to changes in climate and ocean chemistry; and considering threats and opportunities. Socio-economic principles focused on: integrating the social context, local aspirations, and human-environment interactions; 
considering economic and non-economic uses, promoting an equitable distribution of costs and benefits, and respecting and maintaining cultural identity and diversity. Governance principles prioritized establishing and ensuring legitimacy and institutional continuity; implementing collaborative and adaptive management; and, promoting effective management. The paper also examines early efforts to implement the principles, next steps to promote further uptake and application in Mexico, and lessons learned from the process. Thus it provides insights into a practical process and a set of principles that are valuable to inform marine conservation and fisheries management processes elsewhere.

Keywords: marine conservation, fisheries management, marine policy, marine planning, conservation planning, marine reserves, social-ecological systems, MPA management

\section{INTRODUCTION}

Past marine conservation and fisheries management decisions were often driven primarily by ecological objectives and information (Punt and Smith, 2001; Leslie, 2005; Anderson and Seijo, 2011; Cornu et al., 2014). Academics and practitioners alike have long called for a more holistic and integrated approach to environmental decision-making and management on land and the sea, that includes relevant data, knowledge, goals and stakeholders (Folke et al., 2005; Ostrom, 2009; Sayer et al., 2013; Liu et al., 2015; Guerrero and Wilson, 2016; Levin et al., 2016; Cumming and Allen, 2017). The premise is that adopting a social-ecological perspective and incorporating environmental, social, economic, and governance objectives and information will produce more effective, equitable and robust policies and practices. As a result, marine conservation and fisheries management processes around the globe are integrating biophysical, socio-economic, and governance considerations developed through participatory processes.

Examples of more integrative and participatory approaches to marine design and fisheries management abound. These include, for example, the broad uptake of integrated coastal zone management (ICZM) and marine spatial planning (MSP) that incorporate multiple considerations (Ehler and Douvere, 2009; Cornu et al., 2014; Domínguez-Tejo et al., 2016; Gee et al., 2017; Diggon et al., 2019; Frazão Santos et al., 2019; Noble et al., 2019). National legal and policy mandates in many countries now require that social, cultural, economic, and governance aspects are taken into account in fisheries decision-making (Hobday et al., 2016, 2018; Stephenson et al., 2018). There are also a growing number of integrative marine protected areas (MPA) design and management processes around the world that incorporate both social and ecological data (Fernandes et al., 2005; Green et al., 2009; Mangubhai et al., 2015; Diggon et al., 2019). As a result of this increased interest and application, many integrative processes, principles and indicators for marine conservation and fisheries management have been developed (Garcia, 2003; Cicin-Sain and Belfiore, 2005; Ban et al., 2013; Anderson et al., 2015; Long et al., 2015; Stephenson et al., 2017; Alexander et al., 2018). Yet, in practice, integrative marine design and management are still relatively nascent in many parts of the world. Thus, there is a need to continue to document and share additional real-world examples that demonstrate how to move from the development of integrative principles to practical application for ocean sustainability. This paper presents the results of one such participatory process that focused on the development of principles and their application to marine conservation and fisheries management in Mexico (Figure 1).

Over the last half a century, Mexico has been developing a national network of marine conservation initiatives [including marine protected areas (MPAs), fish refuges, state reserves, voluntary community reserves] on both the Pacific and Atlantic coasts (Bezaury-Creel, 2005; Espinosa-Andrade et al., 2020). In this paper, we use the global term "marine reserves" to represent these diverse marine conservation and fisheries management initiatives. Their authors, objectives, levels of protection, and permanence vary. However, during the process that is described in this paper, stakeholders agreed to use the term "zonas de recuperacion pesquera" (fisheries replenishment zones) because they felt that this term was the most inclusive and representative of Mexico's various models. These include the establishment of protected areas under the jurisdiction of the National Commission of Protected Areas (Comisión Nacional de Áreas Naturales Protegidas - CONANP), fish refuges under the National Commission of Aquaculture and Fisheries (Comisión Nacional de Acuacultura y Pesca - CONAPESCA), Refuge Areas to Protect Aquatic Species under the Secretariat of Environment and Natural Resources (Secretaría del Medio Ambiente y Recursos Naturales - SEMARNAT) (Table 1). State governments and local communities also create state and "voluntary" marine reserves respectively see Koch (2015) and Fulton et al. (2019) for more information.

These efforts have substantially increased the number and spatial coverage of Mexico's marine reserves. Estimates of spatial coverage of MPAs in Mexico are in the range of 700,000 km2 or approximately $22-24 \%$ of the exclusive economic zone ${ }^{1}$. Most of these are zoned protected areas that permit fishing in most of the management zone. Core zones and preservation zones inside the protected areas restrict fishing. In total, fishing is prohibited in $4.55 \%$ of the EEZ; however, $98.1 \%$ of the notake area is contained in one MPA (Revillagigedo National Park). This concentration is a concern because fully-protected

\footnotetext{
${ }^{1}$ https://mpatlas.org
} 


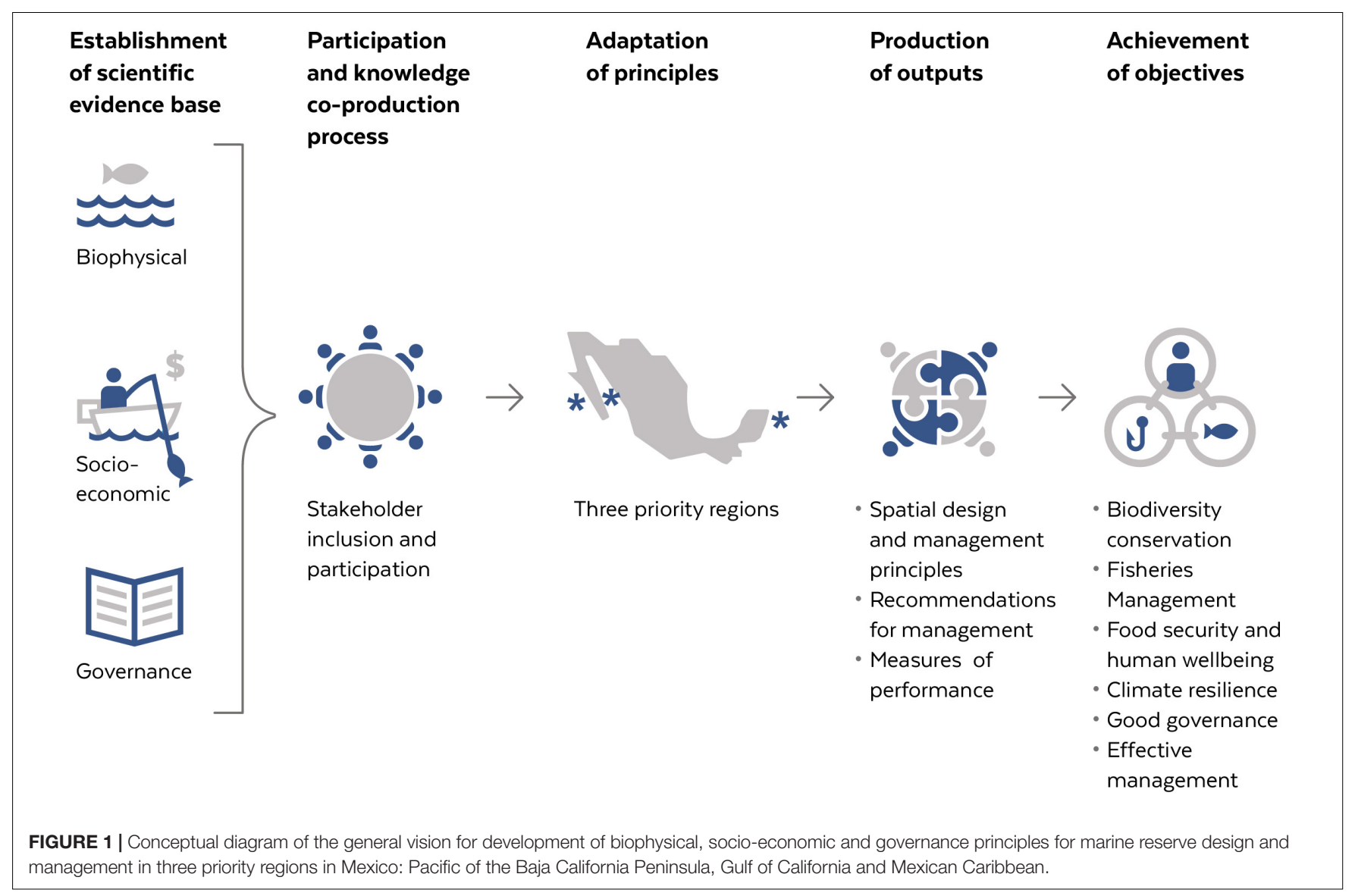

TABLE 1 | Progress on different types of marine conservation initiatives created under different government agencies and jurisdictions in Mexico.

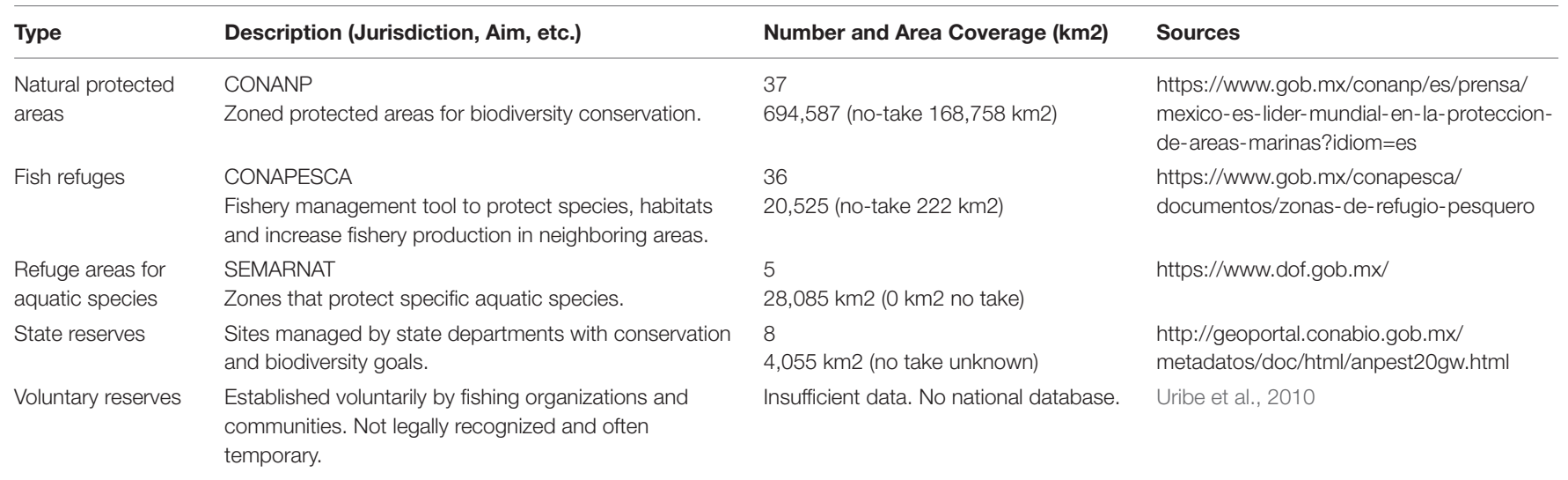

CONANP: Protected area coverage was calculated from CONANP's GIS database (http://sig.conanp.gob.mx/website/pagsig/) and the review of individual protected area management plans to calculate no-take area.

CONAPESCA: The area and no-take status of each fish refuge was calculated with shapefiles created from the coordinates listed in each decree in the Federal Register.

marine reserves are the most effective type of protected areas at conserving biodiversity and replenishing overfished areas (Gell and Roberts, 2003; Lester et al., 2009; Sala and Giakoumi, 2018). For that reason, the Mexican government intends to increase the national coverage of marine reserves and protected areas. In 2018, Mexico and 14 other countries joined the "High Level Panel for a Sustainable Ocean Economy," focused on a sustainable ocean economy in which effective protection, sustainable production and equitable prosperity go hand in hand ${ }^{2}$. To support this vision, during October 2020, CONAPESCA announced the establishment of 77 new no-take fish refuges, covering around 1,000 km2 (López, 2021).

One challenge that has persisted in Mexico is the inconsistent incorporation of biophysical, socio-economic, and governance

${ }^{2}$ oceanpanel.org 
considerations into marine conservation and fisheries management. The lack of coordination among agencies to create a common vision, standards, and tools for protecting marine ecosystems and managing fisheries exacerbates this problem (Weigel et al., 2014). Networks of marine reserves that are coordinated and apply integrated approaches guided by scientific principles are better positioned to maintain or increase long-term fisheries productivity, contribute to marine biodiversity conservation, support climate change adaptation, and help maintain food security and livelihoods in coastal communities (Green et al., 2014; Gurney et al., 2015; Mangubhai et al., 2015; Kockel et al., 2019). They also allow for tradeoffs between ecological and social benefits to be explicitly identified to guide decision making (Munguia-Vega et al., 2018a). Seeing the opportunity to strengthen enabling conditions for marine reserve design and management, several governmental and non-governmental organizations combined efforts and resources to lead a process to co-develop principles and guidance with stakeholders building on global best practices. This paper presents the results of the resultant participatory and collaborative process to develop and apply biophysical, socio-economic and governance principles to the design and management of marine conservation initiatives in Mexico. The paper begins with a discussion of the three priority regions of Mexico that were the focus areas of these processes and a presentation of the steps and methods that were used to co-develop the principles in each site. In conclusion, we discuss how the principles have been promoted and applied, additional actions to mainstream the principles in policy and practice in Mexico, and lessons learned from the process.

\section{METHODS}

\section{Regional Context Descriptions}

Here we describe the three priority regions of Mexico that were the focus of a participatory process to co-develop biophysical, socio-economic, and governance principles for marine reserve design and management: (a) the Pacific region of the Baja California Peninsula, (b) the Gulf of California, and (c) the Mexican Caribbean (Figure 2).

\section{The Pacific Region of the Baja California Peninsula}

The Pacific Region of the Baja California Peninsula ranges from Tijuana, Baja California (BC) in the north, to Cabo San Lucas, Baja California Sur (BCS) in the south. The region represents an area of a biogeographic transition between temperate ecosystems associated with the California Current and the tropical characteristics from the south of the Gulf of California (Durazo and Baumgartner, 2002). These conditions generate diverse oceanographic features that lead to a variety of habitats. The primary habitat in the region's northern part are the forests formed by the kelp Macrocystis pyrifera (ArafehDalmau et al., 2021). This habitat supports the region's high diversity and productivity, providing both nursery and food for many species (Schiel and Foster, 2015; Ramírez-Valdez et al., 2017). Other important habitats, especially relevant in the southern section of the peninsula include intertidal, subtidal and deep rocky reefs, seagrass beds, mangroves and estuaries. These conditions also result in the most diverse fisheries in northwestern Mexico, including high value resources used for export (e.g., abalone, lobster, sea cucumber), and others usually consumed locally or nationally (sea snail, bivalves, shrimp, finfish, elasmobranchs, etc.) (Erisman et al., 2011; Finkbeiner, 2015), generating approximately US\$170 million in fisheries exports, while providing benefits to over 10,000 fishing families. Many of the local community fisheries are managed or co-managed through seasonal fishing, quotas, size limits, seasonal closures and sustainable harvesting practices (McCay et al., 2014). Also, there are over $18,000 \mathrm{~km} 2$ of protected areas in the marine environment (CONANP, 2020), three fish refuges covering 19,935 km2 (CONAPESCA, 2019), and a substantial but unknown number of voluntary marine reserves managed by local communities who have been granted exclusive fishing concessions.

\section{The Gulf of California}

The Gulf of California is known for its great biological richness, endemism and productivity, derived from upwelling events and other oceanographic processes (Lluch-Cota et al., 2007). This region is a biodiversity hotspot that harbors one of the world's top ten ecosystems for endemic species (Roberts et al., 2002). A wide range of habitats can be found, including rocky reefs, wetlands, mangroves, Sargassum forests, rhodoliths and seagrass beds, seamounts, coral and black-coral reefs, which provide important nesting, nursing, reproductive and aggregation sites for both resident and migratory species (Ulloa et al., 2006; Ezcurra et al., 2009; Sánchez-Ibarra et al., 2013). Strong tidal mixing and wind-driven coastal upwelling result in high yearround primary productivity (Lavín and Marinone, 2003), with the area representing over $70 \%$ of the total volume of Mexico's fisheries landings and about $50 \%$ of its value (900 million USD) (Munguia-Vega et al., 2018a). Small-scale fisheries are one of the most important sources of income for coastal communities in the region (Ulloa et al., 2006; Cisneros-Mata, 2010). Aquaculture, tourism, agriculture and cattle ranching are also regionally important and impact the marine environment (Ulloa et al., 2006; Páez-Osuna et al., 2017). Currently, 7\% of the Gulf of California is under some form of protection in Marine Protected Areas (covering 12,383 km2) (Munguia-Vega et al., 2018a; CONANP, 2020) and there are additionally 18 fish refuges (covering $~ 72 \mathrm{~km} 2$ ) (CONAPESCA, 2019); however, the areas that are fully protected cover less than $0.5 \%$ of the region (Munguia-Vega et al., 2018a) and important gaps remain between conservation areas and biodiversity hotspots in the region (Morzaria-Luna et al., 2018).

\section{Mexican Caribbean}

The Mesoamerican Reef System (MAR) is the longest coral reef ecosystem in the Western Hemisphere, supporting unique biodiversity (Roberts et al., 2002) and spanning more than $1,000 \mathrm{~km}$ from Cabo Catoche, Mexico, through Belize and Guatemala, to the Bay Islands, Honduras (Kramer et al., 2015). 


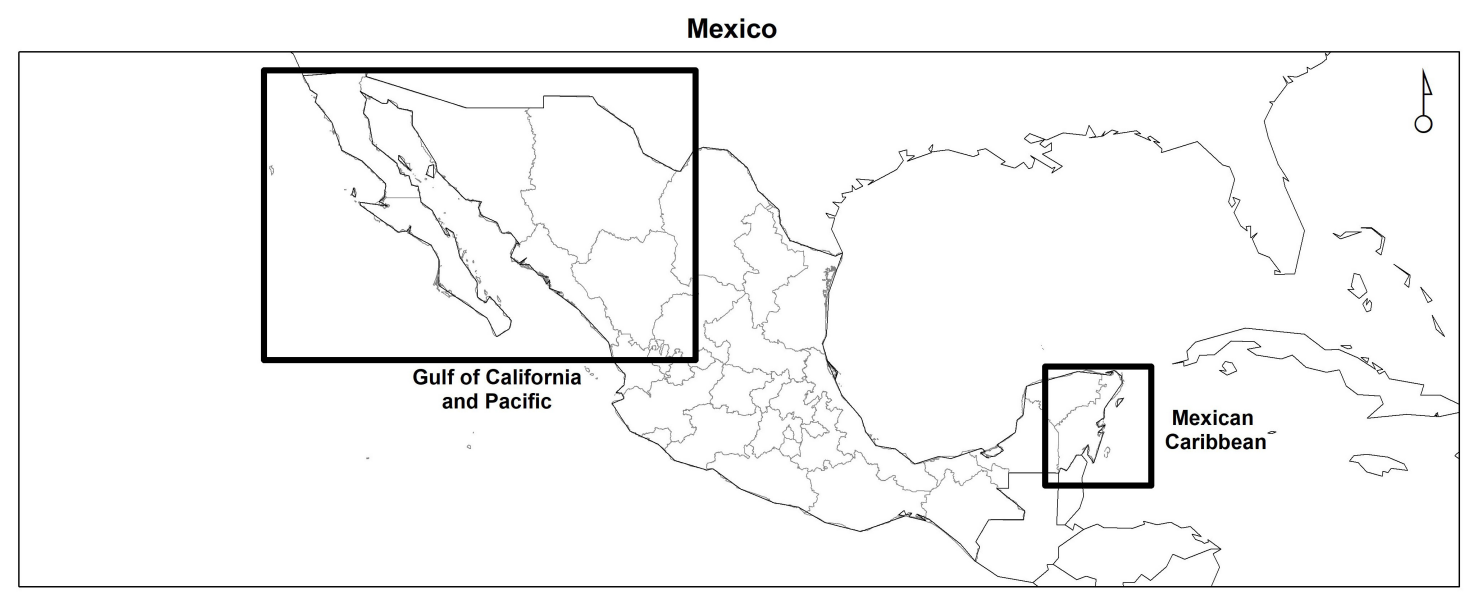

Gulf of California \& Pacific

Mexican Caribbean
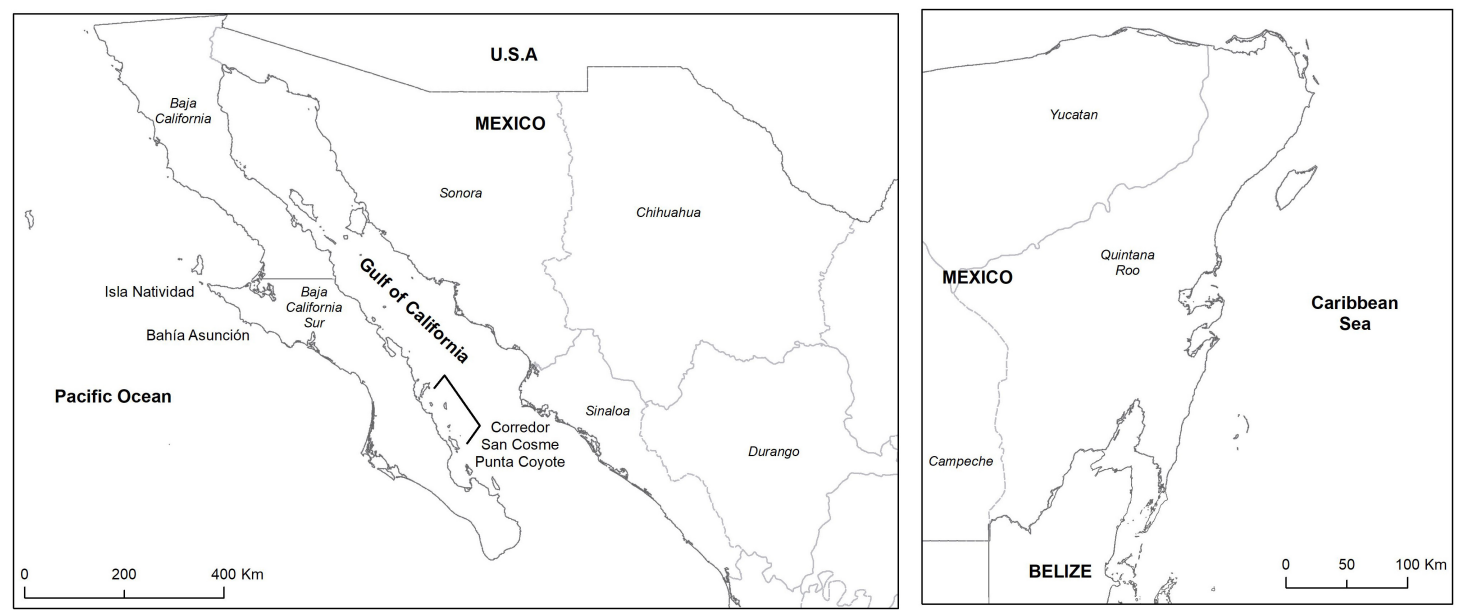

FIGURE 2 | Map of location of three focal areas

The region includes at least five distinct ecological areas, ranging from warm, clear waters offshore, to turbid inshore areas around bays and cold areas subjected to upwelling in the north of the ecoregion (Chollett et al., 2012, 2017). The MAR is a priority ecoregion (Olson and Dinerstein, 2002), supporting the economies and culturally rich livelihoods of over 17 million people. The Tulum Declaration between the heads of state of the four countries in 1997 set the conservation agenda, inspiring the creation of a range of marine protected areas, coastal management plans and reef monitoring programs. The Mexican Caribbean portion of the MAR, representing the state of Quintana Roo, has a population of 1.8 million (2020) (INEGI, 2020). Tourism is by far the biggest economic driver, with the state receiving 23 million visitors in 2019, which represent $87 \%$ of the region's Gross Domestic Product (Quintana Roo Gobierno del Estado, 2020). There are approximately 2,200 smallscale fishers who target lobster (Panulirus argus) and finfish (principally groupers and snappers), as well as Queen conch (Lobatus gigas) in Banco Chinchorro, and octopus (Octopus maya, Octopus vulgaris) in the northern part of the state (Green et al., 2017). There are many protected areas, with $97 \%$ of the territorial sea being inside one of 12 federal protected areas covering 63,837 km2 (CONANP, 2020). In addition, there are currently 14 fish refuges $(178 \mathrm{~km} 2)$. The network of protected areas and no take zones currently protects $3.96 \%$ of the territorial sea within this region from fishing. While fish refuges do provide benefits to fish biomass and diversity, the current piecemeal design of the network is not considered effective (EspinosaAndrade et al., 2020) and thus there is a need for a more science-driven MPA network design in the region.

\section{Steps in the Process to Co-produce the Principles}

In the three regions of the country, multiple stakeholders (government agencies, non-profit organizations, academic institutions, fishing organizations, etc.) joined a participatory process to co-develop the principles. The benefits of participatory policy development processes are well documented and include ensuring that diverse actors and perspectives inform the process, enhancing the fit of policy proposals to the social and political context, improving the legitimacy and ownership of outputs, and increasing the likelihood of application of recommendations 
(Borrini-Feyerabend et al., 2007; Armitage et al., 2010; Gaymer et al., 2014; Karrasch et al., 2017; d'Armengol et al., 2018; Norström et al., 2020). Knowledge co-production, which is a topic that is receiving growing attention in sustainability science and natural resource management (Djenontin and Meadow, 2018; Lemos et al., 2018; Harvey et al., 2019; Mitchell and Leach, 2019; Wyborn et al., 2019; Cooke et al., 2020), refers to "iterative and collaborative processes involving diverse types of expertise, knowledge and actors to produce context-specific knowledge and pathways toward a sustainable future" (Norström et al., 2020, 2). There are a growing number of examples where participatory processes were used to co-develop principles or indicators for environmental or marine management (Reed et al., 2006; Bohunovsky et al., 2010; Espinosa-Romero et al., 2011; Marques et al., 2011; Biedenweg et al., 2014; Sterling et al., 2017; Gilani et al., 2018).

The participatory processes used to co-develop the principles and guidance in each of the three priority regions followed similar steps - which included:

1. Visioning, fundraising and creating a core team - We first developed a vision focusing on the needs and opportunities in each region, obtaining the necessary funding and capacity to support and create a multistakeholder leadership team (from a national and international level) who have led similar processes in other countries. The leadership team ensured close coordination, documentation, sound planning and adaptive management during the different stages of the process.

2. Conducting a literature review - We conducted a review of existing literature to identify candidate biophysical, socio-economic, and governance principles used in marine conservation design and management elsewhere (see review below), that we could use for group deliberations and adapt to each region.

3. Gathering background information - Next, we gather background information on each region, including biophysical, socio-economic, and governance information as well as the number and type of existing marine reserves. This was used as background information for the workshops, and helped to provide a clear rationale for each process and to identify key information gaps.
4. Convening stakeholder workshops - Then, we convened a series of participatory workshops with stakeholders in each region. Stakeholders were identified through creating a stakeholder map to ensure representation of different organizations, sectors and areas of expertise. The process to identify, develop, and adapt biophysical principles started in the Gulf of California region, with four workshops held between 2015 and 2016. The process continued in the Mexican Caribbean in 2016 with two workshops and finally, in the Pacific of Baja California Peninsula with two workshops in 2017 and 2019. Also, multidisciplinary groups identified Socioeconomic and governance principles in 2016 (in two workshops in the Gulf of California region), one workshop focusing on the Mexican Caribbean in 2018, and one workshop in 2019 with participants from the Pacific of Baja California Peninsula. The 12 workshops were facilitated by scientific experts and non-profit organizations (NGO) staff, structured around a series of participatory activities and discussions, and included more than 180 participants (of which $44 \%$ were women and $56 \%$ were men), from over 70 institutions, including representatives from government, NGOs, fishing organizations, academic institutions and others (private sector, foundations, alliances, independent researchers; see Table 2).

5. Drafting and refining principles and guidance - Based on the discussions at the workshops, a draft set of principles (biophysical, socioeconomic and governance) was developed, circulated for comments and feedback, and refined iteratively for each region. In some cases, scientific working groups were convened to further refine the principles, generate new data, and develop models (Munguia-Vega, 2018; Munguia-Vega et al., 2018a). The final principles were then elaborated in a series of reports and publications, that also provide guidance on how to apply the principles to design and management of marine reserves (Bennett et al., 2017a; Green et al., 2017; MunguiaVega, 2018; Munguia-Vega et al., 2018a; COBI and TNC, 2019a,b).

6. Communicating and socializing the principles and guidance - To promote awareness, uptake and application of the principles, the results of the workshops were

TABLE 2 | Groups and numbers of stakeholders in each group included in each participatory workshop to design biophysical (BIO) or socio-economic and governance principles (SEG).

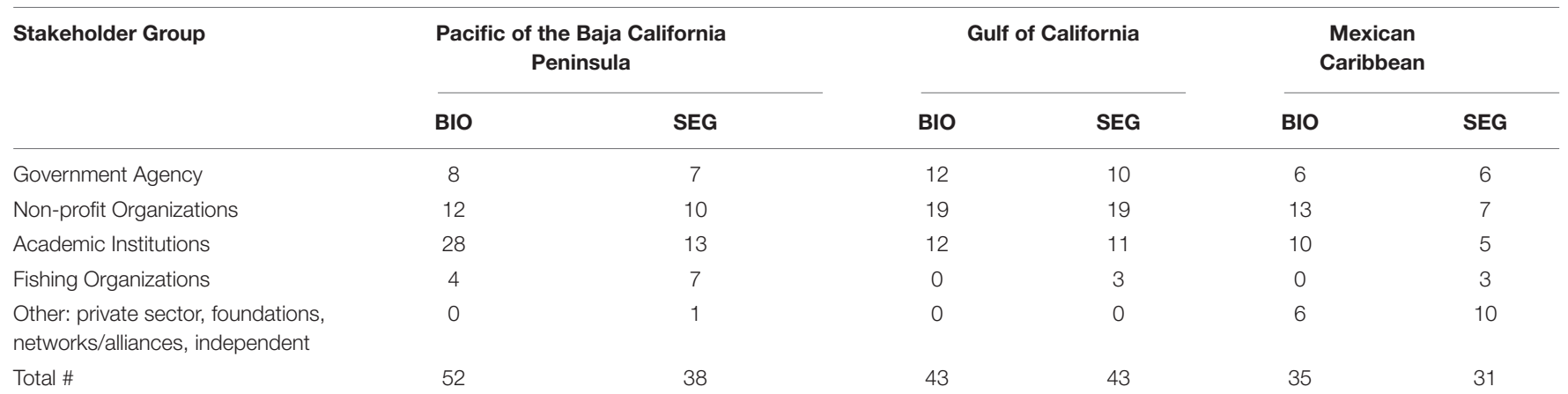


then shared and communicated broadly to regional government decision-makers, NGO practitioners, and local communities. A general summary of the adapted principles on the three regions was distributed to the workshop attendees and shared on social media, as well as promoted in several meetings with government agencies. An outreach brochure describing the principles for the design, establishment and effective management of marine reserves in Mexico was produced for the general public, and in some regions lessons from the application of principles were documented in case studies (Mancha-Cisneros et al., 2018a,b,c).

7. Promoting and supporting application to policy and in practice - The final and arguably the most important step in the process has been, and will continue to be, to promote and support the application of the biophysical, socioeconomic and governance principles by decision makers at all spatial scales and within different governance regimes. This includes, for example, informing national marine conservation policy and place-based marine reserves in each region. For example, we have continued scientific efforts to refine the design principles (Munguia-Vega, 2018; Munguia-Vega et al., 2018a), participated in marine planning processes (e.g., applying the principles to the subzoning of the Mexican Caribbean Biosphere Reserve), worked with the national government to incorporate principles into law and policy (e.g., updating the NOM-049 that provides the framework for establishing fish refuges), and engaged with communities regarding how to adapt the principles to design voluntary reserves (see examples in Boxes 1, 2). Ideas for future engagements and applications are discussed later in the paper.

These steps were used in each region with adjustments for contextual factors, available budgets, timelines and logistics.

\section{RESULTS}

This section, presents insights from our literature review, the resultant biophysical, socio-economic, and governance principles identified through the workshops, and an overview of early efforts to apply the principles to policy and practice.

\section{Insights From the Literature Review}

Our review of the academic and gray literature focused on understanding the biophysical, socio-economic, or governance considerations that might guide the design and management of marine conservation initiatives to achieve various objectives. Table 3 summarizes insights from this literature.

\section{Biophysical Considerations}

The efficacy of marine conservation initiatives at achieving positive ecological and fisheries outcomes depends on consideration of biophysical factors (Edgar et al., 2014; Turnbull et al., 2018; Lorenzo et al., 2020). Key biophysical considerations are related to protecting habitats and species, enabling fisheries to recover, increasing resilience to climate change, and threat avoidance or reduction (Green et al., 2014). A central consideration is protecting biodiversity, which requires the representation of surrogates such as habitats or species (Ward et al., 1999; Gaines et al., 2010; Maxwell et al., 2020), adequate replication of sites to spread risks in case of disasters (Saarman et al., 2013; Green et al., 2014), and the protection of areas with special, unique or endangered habitats or species inside networks of protected areas (Green et al., 2014, 2015; Klein et al., 2015). Special and unique areas include critical areas in the life history of focal species (e.g., nursery, spawning or breeding areas), or areas with high productivity, endemism or diversity. The design of marine reserves for the recovery of fisheries and conservation of rare and threatened species (e.g., sea turtles), in particular, necessitates: connecting protected areas to support movement of larvae, juveniles and adults (Green et al., 2015; Magris et al., 2018); allowing adequate time for recovery of stocks (Green et al., 2014; Duarte et al., 2020) and protecting areas and time periods that support critical life stages or that are highly productive (Erisman et al., 2017; Dunn et al., 2019; Berkström et al., 2020).

Climate change, and associated changes to ocean conditions including temperature rise and acidity, requires that marine conservation takes into account the resilience or adaptive capacity of habitats and species (Micheli et al., 2012; Roberts et al., 2017; Wilson et al., 2020; Arafeh-Dalmau et al., 2021), the effects of climate change on ecosystem functioning and different life stages of species (Dahlke et al., 2020; Trisos et al., 2020), and adopts a precautionary approach that takes uncertainty into account in the decisions related to representation and risk spreading (Tittensor et al., 2019; Pinsky et al., 2020). Finally, since threats can impact ecosystems and species and undermine the effectiveness of recovery efforts - consideration should be given to the siting of marine conservation initiatives to avoid areas with high populations, levels of development, or cumulative impacts unless there are efforts to mitigate or manage these existential threats (Ban et al., 2010; Cinner et al., 2018b; Halpern et al., 2019).

\section{Socio-Economic Considerations}

It is increasingly recognized that social, economic and cultural considerations need to be taken into account in the planning and management of marine conservation initiatives (Ban et al., 2013; Cornu et al., 2014; Kittinger et al., 2014; Grimmel et al., 2019), with the rationale being that this is both a more equitable and just approach to conservation and it can also increase the effectiveness of conservation (Aswani et al., 2017; Bennett et al., 2017b). A key consideration is the social and economic impacts of marine conservation - which raises the importance for marine conservation planners and managers to recognize and take into account the diversity of stakeand rights-holders, uses, tenure and rights (Reed et al., 2009; Gunton et al., 2010; Kittinger et al., 2014), existing extractive and non-extractive economic activities (Mangubhai et al., 2015; Ruiz-Frau et al., 2015), the equitable distribution of benefits and harms (Halpern et al., 2013; Gurney et al., 2015; Kleiber et al., 2018), and actions that might be taken to reduce, manage or compensate for negative consequences (Bennett et al., 2017b; 
BOX 1 | Community workshop in Baja California Sur: applying biophysical, socioeconomic and governance principles for designing community marine reserves.

Bahía Asunción is located in the Pacific region of the Baja California Peninsula, $~ 800 \mathrm{~km}$ north of La Paz. The local fishing cooperative SCPP California de San Ignacio SCL, was the first cooperative created in Baja California, in 1939. Their fishing practices have always been associated with sustainable fishing and marine biodiversity preservation, selling products with high quality standards and implementing marine reserves for commercial species.

In 2019, the California San Ignacio cooperative requested the support of a neighboring community (Isla Natividad), which has had marine reserves since 2006. A workshop was held in order to select the most suitable sites to implement their marine reserves, based on the experience and lessons learned from Isla Natividad, and on the biophysical, socioeconomic and governance principles identified for this region. The cooperative designated the potential sites, and at the end of the meeting, they selected four zones considering Isla Natividad's experience in fish production, conservation objectives (increasing abundance of benthic commercial species like abalone and lobster) and the design principles. To date, the cooperative members have voted in favor of implementing two marine reserves in their fishing areas, maximizing their potential of success by incorporating local knowledge and the design principles.

Kaplan-Hallam and Bennett, 2018). Marine conservation design and management also increasingly incorporate cultural considerations, which include local or traditional knowledge (Drew, 2005; Aswani and Lauer, 2006), diverse perceptions of cultural values related to the marine environment (Klain and Chan, 2012; Blake et al., 2017), cultural practices (e.g., harvesting, management) or customs (Cinner and Aswani, 2007; Aswani, 2017), as well as species or areas that are important for cultural uses or identity (Poe et al., 2014; Gee et al., 2017). Additional social considerations that might be taken into account in marine conservation include: human well-being in local populations (Biedenweg et al., 2016; Ban et al., 2019; Gollan et al., 2019), the quality of social relations or levels of conflict (Young et al., 2016; Rosales, 2018), gender equality (Baker-Médard, 2017; Kleiber et al., 2018), social agency and empowerment of local groups (Lansing, 2009; Diedrich et al., 2017), and of the social adaptive capacity of local resource users to new restrictions on access or to new livelihood opportunities (Armitage, 2005; Bennett et al., 2014; Maldonado and del Pilar Moreno-Sánchez, 2014; Cinner et al., 2018a). While integrating social considerations into marine conservation and planning is recognized as important, the practice is still relatively nascent compared to biophysical considerations and there is substantial variation in approaches and application across sites (Cornu et al., 2014; Grimmel et al., 2019).

\section{Governance Considerations}

Governance is understood to be one of the most important factors for the environmental effectiveness and longevity of conservation initiatives (Ostrom, 1999; Lockwood et al., 2010; Armitage et al., 2012). We use the term governance broadly to refer to the set of formal and informal policies, institutions and processes that influence how decisions are made, who makes decisions, and what actions are taken as well as the resulting resources, plans and actions of applied management (Lockwood, 2010; Bennett and Satterfield, 2018). Overarching governance factors related to the effective design and management of marine conservation initiatives include management effectiveness (Pomeroy et al., 2004; RodríguezRodríguez et al., 2015), adaptive management (Armitage, 2005; Boyd et al., 2015), good governance (Lockwood, 2010; Borrini-Feyerabend and Hill, 2015) and institutional robustness (Anderies and Janssen, 2013; Morrison, 2017). The effectiveness of management relies on having a clear vision and documented plan or strategy (Pomeroy et al., 2004; Lockwood, 2010; Borrini-Feyerabend et al., 2013), adequate financial and human capacity (Pomeroy et al., 2004; Lockwood, 2010; Gill et al., 2017), sustainable financing mechanisms (Emerton et al., 2006; Ison et al., 2018), evidence-based decision-making processes (Tengö et al., 2014; Charnley et al., 2017), and coordination with organizations and activities in the broader seascape (Wyborn, 2015; Abe et al., 2016). Key factors underlying adaptive management include mechanisms, such as monitoring and evaluation or communities of practice, to facilitate and document collective or social learning (Berkes and Turner, 2006; Armitage and Plummer, 2011; Maida and Beck, 2016), a spirit of innovation and experimentation (Westley et al., 2011; Chaffin et al., 2016), foresight thinking to plan for expected 
BOX 2 | Fish refuge network in the San Cosme-Punta Coyote Corridor in the Gulf of California. (A) shows aclose up of the northernmost fish refuge, San Marcial, first established in 2012 (light blue) and then renewed and expanded in 2017 (shaded). (B) displays the results of the prioritization method which indicate the areas (green dots) with optimal conditions or potential to be included as fishery refuge. The red square represents the fish refuge San Marcial in 2012.

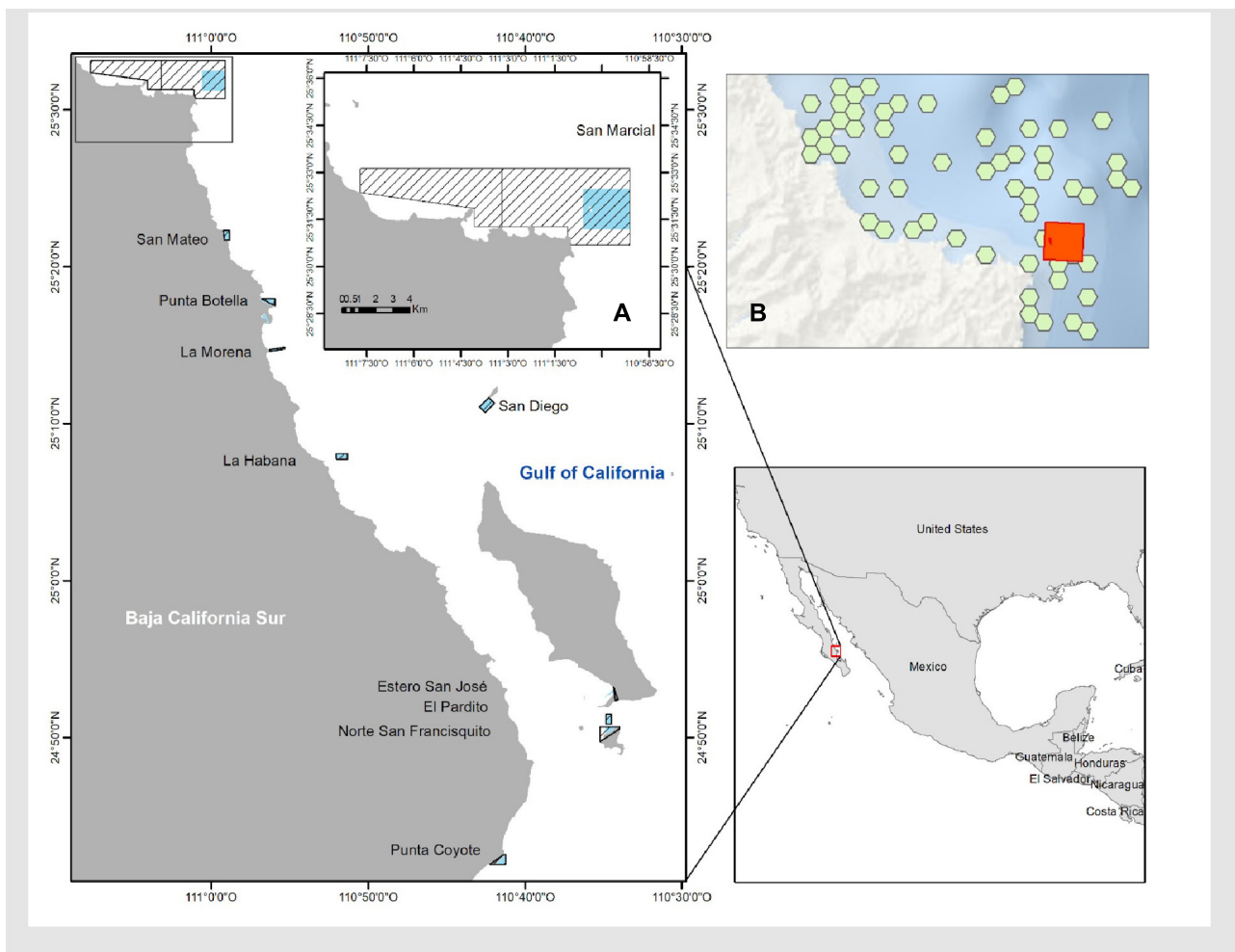

The first fish refuge network in Mexico was established in 2012, for a five year period, covering the marine corridor from San Cosme-Punta Coyote, BCS. The design of the network was the result of a participatory process that included 150 people, including 13 coastal communities, government representatives, academics and non-profit organizations. The decisions around the selection of these areas were mostly weighted upon social importance and perceptions.

In 2017, at the conclusion of the five year period, the stakeholders conducted an evaluation to determine whether the fish refuges should be renovated, modified, or eliminated. During this process, fishing communities became more familiarized with biophysical, socioeconomic and governance information gathered during the previous five years. This new understanding played a key role in the decision to increase the size of one of the fish refuges by a factor of five and to create a new one. During this process, local NGOs and researchers applied a prioritization method using Marxan to incorporate the spatial biophysical principles and determine the ideal design of the network, considering key criteria. When compared to the map of suggested new areas, this exercise allowed us to validate and support the proposed renewed design of the network.

or unexpected future changes (Tschakert and Dietrich, 2010; Boyd et al., 2015), and clear processes to ensure that corrective adaptations are taken (Dietz et al., 2003; Armitage et al., 2010). Good quality governance processes - also called "good governance" or "equitable governance" - involve attention to recognition of the diverse perspectives and needs of all stakeholder groups (McDermott et al., 2013; Borrini-Feyerabend and Hill, 2015), participatory and inclusive decision-making processes (Reed, 2008; Lockwood, 2010; Havard et al., 2015), attention to equity in the distribution of positive and negative impacts (Pascual et al., 2014; Zafra-Calvo et al., 2017), and respect for human rights (Jonas et al., 2016; Bennett et al., 2017b). Perceptions of good governance also leads to legitimacy among stakeholders, and thus engenders long-term support for conservation among stakeholders (Dalton et al., 2012; Bennett et al., 2019). The legitimacy and continuity of institutions also requires that organizations at various scales (i.e., local, regional, national) remain autonomous but connected (Marshall, 2007; Bodin, 2017), to facilitate information sharing and coordination of actions (Cohen et al., 2012; Barnes et al., 2016), and 
that they work toward a common vision (Ostrom, 2010; Carlisle and Gruby, 2017).

\section{Principles and Guidance From Stakeholder Workshops}

Each process, with its participatory workshops, produced a set of principles and guidance for biophysical, socio-economic, and governance considerations for the three priority regions (see Table 4). These were developed using the best available scientific information, local knowledge of stakeholders and adapting the insights and principles found in the literature to the local context - and when none existed developing new principles and guidance. There were six categories of biophysical principles: habitat representation and risk spreading; protecting critical, special and unique areas; incorporating connectivity; allowing time for recovery; adapting to changes in climate and ocean chemistry; and considering threats and opportunities. Three categories of socioeconomic principles emerged: integrating the social context, local aspirations, and human-environment interactions; considering economic and non-economic uses, and promote an equitable distribution of costs and benefits; and respecting and maintaining cultural identity and diversity. The workshops also produced three categories of governance principles: establishing and ensuring legitimacy and institutional continuity; implementing collaborative and adaptive management; and promoting effective management.

Within the broad categories, the principles were quite similar overall in the three geographic regions. There were, however, some key differences in the principles that came out from the workshops due to regional variation. Overall, the biophysical principles were highly aligned but differences came out in their application. For example, while the same overarching biophysical principles were used (e.g., representation, replication, critical areas, size, spacing), the specifics of how they were to be applied in each region differed due to variation in the habitats and species that were the focus of protection. A key difference was the possibility of larger marine reserves on the Pacific Coast of BCS versus networks of smaller marine reserves in the Gulf of California and Mexican Caribbean. The reason for this difference was related to both density of users and threats, as well as the number of key biogeographic regions, habitats important for fish spawning, and the speed of currents and larval dispersal. Another difference is the transboundary nature of the northern Pacific Coast of Baja California (Arafeh-Dalmau et al., 2017), and Mesoamerican Reef (Chollett et al., 2017) which necessitates that the process take into account the connectivity of species and habitats with California, United States, and Belize, respectively. One major variation in the socio-economic principles was related to the attention given to culture and local knowledge in the Gulf of California and Caribbean due the presence of Indigenous groups. Finally, the main differences related to the governance principles focused on the promotion of adaptive management, commitment of actors and gender equity in the Pacific region, the creation of a network of supportive organizations and promotion of good social relations with and between stakeholders in the Gulf of California and attention when implementing marine reserves, to human rights and legitimacy, since eco-tourism is the main priority of government in the Mexican Caribbean.

Taken together, these outcomes highlight both the generality of principles, and therefore their broad applicability to other regions, and also the context dependency of their implementation, and need to address the specific characteristics of planning regions (e.g., biogeographic boundaries, the presence of indigenous groups and customary rights, and pre-existing conservation and management measures).

\section{Moving From Principles to Practice - Initial Actions and Efforts}

Since the completion of the principles, a number of efforts have been made to promote and apply them. These include the following six types of actions: (a) communicating and socializing the principles, (b) forming scientific working groups and projects, (c) evaluating current networks and incorporating principles into marine spatial design processes, (d) conducting community workshops on application of principles, (e) working to formalize principles in law and policy, and (f) replicating and scaling the identification and use of principles elsewhere. First, the principles were communicated to and socialized with stakeholders at various scales, including government agencies to encourage the adoption of the principles at a regional scale, fishing communities (e.g., the Comcaac indigenous nation in the northern Gulf of California) to examine how they might be used in the planning of marine reserves at a local scale, and to academics in meetings or conferences at national and international scale. Second, scientific working groups were formed to carry out research projects motivated by the principles. These groups compiled existing information, identified data gaps, and developed new databases [e.g., of habitats, biodiversity hotspots, patterns of larval dispersal, movement of focal species, species recovery rates, effects of climate change (Munguia-Vega et al., 2018a; Arafeh-Dalmau et al., 2021)]. They also applied this information to develop new models and identify priority areas for expanding existing networks of marine reserves (ÁlvarezRomero et al., 2018), adapting these models with stakeholder and community input (Morzaria-Luna et al., 2020a,b), and publishing academic papers.

Third, the principles are starting to be integrated into marine spatial design processes and used to evaluate existing networks of marine reserves. Three initial projects include an evaluation of the current representation of each principle in the three regions (i.e., Pacific region, Gulf of California and the Mexican Caribbean) (Espinosa-Andrade, 2019a,b,c), a spatial prioritization analysis with Marxan (Ball et al., 2009) to identify priority areas of conservation in the Gulf of California (MunguiaVega et al., 2018b), and the application of the biophysical principles during marine spatial planning for 26 fish refuges in the northern Gulf of California (Morzaria-Luna et al., 2020a,b).

Fourth, the principles have been used to guide deliberations in local community workshops focused on marine conservation and fisheries management. For example, during a workshop in Bahía Asunción in Baja California Sur the principles were applied during the design of community marine reserves (see 
TABLE 3 | Summary of biophysical, socio-economic, and governance considerations to achieve various objectives in marine conservation design and management.

\begin{tabular}{|c|c|c|}
\hline Category & Objectives & Related considerations \\
\hline \multirow[t]{4}{*}{ Biophysical } & Protecting the diversity of habitats and species & $\begin{array}{l}\text { habitat representation and replication, critical, unique and special areas and species } \\
\text { (e.g., endemic, rare and threatened), connectivity, time for recovery }\end{array}$ \\
\hline & $\begin{array}{l}\text { Promote the persistence and recovery of exploited } \\
\text { populations }\end{array}$ & $\begin{array}{l}\text { adult habitat protections (e.g., no take areas), connectivity, recuperation time, critical } \\
\text { areas and life stages (e.g., spawning and nursery areas) }\end{array}$ \\
\hline & Enhancing resilience to climate change & $\begin{array}{l}\text { threats to and adaptive capacity of focal habitats and species, distribution and } \\
\text { dispersion of risk, life cycle of species, ecosystem functioning }\end{array}$ \\
\hline & Avoiding and managing threats & $\begin{array}{l}\text { level of and proximity to anthropogenic threats (e.g., human population centers and } \\
\text { industry), cumulative impacts, threat mitigation and management }\end{array}$ \\
\hline \multirow[t]{3}{*}{ Socio-economic } & Incorporating social considerations & $\begin{array}{l}\text { human well-being, social relations and capital, levels of conflict, social agency and } \\
\text { empowerment, social adaptive capacity }\end{array}$ \\
\hline & Maintaining cultural connections and practices & $\begin{array}{l}\text { local or traditional knowledge, cultural values and perspectives, cultural practices or } \\
\text { customs, traditional uses, culturally important species or areas }\end{array}$ \\
\hline & $\begin{array}{l}\text { Maximizing benefits and minimizing } \\
\text { socio-economic costs }\end{array}$ & $\begin{array}{l}\text { stakeholders, uses and rights, extractive and non-extractive economic activities, } \\
\text { trade-offs, distribution of benefits and costs, creation of economic opportunities, } \\
\text { management of social impacts, mitigation of negative consequences }\end{array}$ \\
\hline \multirow[t]{4}{*}{ Governance } & Supporting effective management & $\begin{array}{l}\text { clear vision and strategy, documented management plan, financial and human capacity, } \\
\text { sustainable financing mechanisms, evidence-based decision-making, effective } \\
\text { management in broader seascape }\end{array}$ \\
\hline & Facilitating adaptive management & $\begin{array}{l}\text { social learning processes (e.g., monitoring and evaluation, community of practice), } \\
\text { innovation and experimentation, foresight thinking, clear mechanisms to prompt } \\
\text { adaptations }\end{array}$ \\
\hline & Implementing collaborative and good governance & $\begin{array}{l}\text { recognition of diverse stakeholder groups, participatory and inclusive decision-making } \\
\text { processes, attention to equity, respect for human rights, transparency and } \\
\text { accountability }\end{array}$ \\
\hline & Maintaining institutional robustness & $\begin{array}{l}\text { legitimacy, organizations at various scales (e.g., local, regional, national) are } \\
\text { autonomous but connected, information sharing, coordination of actions, working } \\
\text { toward a common vision }\end{array}$ \\
\hline
\end{tabular}

Box 1), and in San Cosme-Punta Coyote Corridor in Baja California Sur, fishing communities adapted the principles during the redesign and renewal of their local fish refuges (see Box 2). A similar process was conducted in the Mexican Caribbean with local fishers, wherein they reviewed each principle and discussed whether any changes would be made to the design of their local fish refuges. Fifth, the team has been working in collaboration with various agencies and levels of government to institutionalize the principles in national laws and the policies of fisheries and conservation agencies (NGOs, CONANP, INAPESCA, and CONAPESCA). In 2019, the NOM-049 (which is the law that provides the framework for establishing fish refuges at national level) completed its 5year term and suggestions were made, including considering the principles during the different stages of fish refuges design, implementation, management and renewal. In November 2019, CONAPESCA published the modified project of the NOM-049, which promotes the incorporation of biophysical, socioeconomic and governance principles in the proposals for fish refuge areas, as a contribution to optimize the expected benefits in the management, protection and recovery of fishery resources, as well as in strengthening the participation of various sectors in the decision making (SEGOB, 2019). Finally, inspired by our processes and outputs, similar processes of identification of biophysical, socioeconomic and governance principles were also conducted in other countries in the region. In the Mesoamerican Reef region, Mexico, Belize, Honduras and Guatemala jointly developed biophysical principles (Green et al., 2017) and
Honduras and Guatemala also developed socio-economic and governance principles aligned with their national characteristics and contexts (Bonilla, 2019).

\section{DISCUSSION}

In this paper, we present an overview of the process and outcomes of a multi-year effort to produce and apply a set of biophysical, socio-economic and governance principles to marine conservation and fisheries management in Mexico. The principles that resulted from the three regional processes were quite similar, but had some variation due to different social and ecological contexts. In the past few years, significant efforts have been made to promote and apply the principles but much remains to be done in this regard. In this discussion section of the paper, we compare the principles and process with initiatives from elsewhere, discuss further steps that still need to be taken to promote uptake and increase application of the principles, and examine lessons learned to guide others embarking on similar processes elsewhere.

\section{Comparison With Other Initiatives}

Many other processes around the world have developed principles to guide marine conservation planning and fisheries management. While many earlier efforts focused primarily on ecological considerations, it is becoming common to develop and apply an integrated set of biophysical, socio-economic, 
TABLE 4 | Overview of biophysical, socio-economic and governance principles across the three priority regions.

\begin{tabular}{|c|c|c|}
\hline & \multirow[t]{2}{*}{ Category } & \multirow[b]{2}{*}{ Pacific of Baja California Peninsula } \\
\hline & & \\
\hline \multirow[t]{3}{*}{ Biophysical } & $\begin{array}{l}\text { Habitat representation } \\
\text { and risk spreading }\end{array}$ & $\begin{array}{l}\text { Represent } 20-30 \% \text { of each major } \\
\text { habitat type (e.g., kelp forest, rocky } \\
\text { reefs). } \\
\text { Protect at least three widely distributed } \\
\text { replicates of each major habitat. }\end{array}$ \\
\hline & $\begin{array}{l}\text { Protecting critical, special } \\
\text { and unique areas }\end{array}$ & $\begin{array}{l}\text { Protect critical areas in the life history } \\
\text { of focal species in marine reserves } \\
\text { (e.g., spawning or nursery areas),sites } \\
\text { with high endemism or abundance, } \\
\text { healthy areas, etc. }\end{array}$ \\
\hline & Incorporating connectivity & $\begin{array}{l}\text { Consider movement patterns of adults } \\
\text { and juveniles of focal species when } \\
\text { determining the size of marine } \\
\text { reserves. } \\
\text { Design a network of marine reserves to } \\
\text { maintain larval connectivity and } \\
\text { maximize dispersal to fishing areas. } \\
\text { Establish marine reserves that are } \\
\text { large enough to contain all the } \\
\text { habitats used during the life } \\
\text { history of focal species; or } \\
\text { networks that are close enough to } \\
\text { allow focal species to move among } \\
\text { protected habitats during their life } \\
\text { cycle. }\end{array}$ \\
\hline
\end{tabular}

Allowing time for recovery Establish marine reserves for $>25$ years, preferably permanently, for conservation purposes and to enhance fisheries production. Seasonal marine reserves can be used to protect focal species during critical life stages.

Adapting to changes in climate and ocean chemistry

Considering threats and opportunities

Socio-economic Integrating the social context, local aspirations, and human- environment interactions to maintain and promote social
Prioritize areas for protection where habitats and species are likely to be more resistant or resilient to climate change.

Increase protection of key species groups where they play important key functional roles in ecosystem resilience.

Address uncertainty by spreading the risk and adding a buffer area.

Prioritize placing marine reserves where there are, or are more likely to be, low levels of threats now and in future.

Diagnose the state of social welfare and manage marine reserves in order well-being.

Promote community empowerment, social connectivity and positive relationships with stakeholders. Achieve effective communication to the different educational levels and social groups. All information to be disseminated, must be clear and in accordance with the actors to achieve effective awareness.

Ensure that all actors have the same possibilities of receiving the social benefits derived from the marine reserves.
Principle

Gulf of California
Represent 10-30\% of each major
habitat type (e.g., rocky reefs, seaweed
forests).
Protect at least three widely distributed
replicates of each major habitat.

Protect critical areas in the life history of focal species in marine reserves (e.g., spawning or nursery areas), sites with high endemism or abundance, healthy areas, etc.

Consider movement patterns of adults and juveniles of focal species when determining the size of marine reserves.

Design a network of marine reserves to maintain larval connectivity and maximize dispersal to fishing areas.

Protect all key habitats used by focal species throughout their lives within individual marine reserves, or ensure that reserves are close enough to allow focal species to move among habitats. Use compact marine reserves shapes and include whole ecological units.

Space marine reserves less than 50-200 km apart in the direction of the predominant current flow during spawning time.

Establish marine reserves for $>25$ years, preferably permanently, for conservation purposes and to enhance fisheries production.

Prioritize areas for protection where habitats and species are likely to be more resistant or resilient to climate change. Consider climate change effects on: (1) larval dispersal, and implications for the location, number and spacing of reserves, (2) life cycle of species for the duration and location of reserves, and (3) ecosystem function and dynamics for biophysical principles in general.

Prioritize placing marine reserves where there are, or are more likely to be, low levels of threats now and in future.

Diagnose the state of social welfare and manage marine reserves in order to maintain and promote social well-being. Promote community empowerment, social connectivity and positive relationships with stakeholders.

The local knowledge of users is integrated into the design, implementation and evaluation of management initiatives.
Mexican Caribbean

Represent $20-30 \%$ of each major habitat type (e.g., coral reefs, mangroves).

Protect at least three widely distributed replicates of each major habitat.

Protect critical areas in the life history of focal species in marine reserves (e.g., spawning or nursery areas), sites with high endemism or abundance, healthy areas, etc.

Consider movement patterns of adults and juveniles of focal species when determining the size of marine reserves.

Design a network of marine reserves to maintain larval connectivity and maximize dispersal to fishing areas. Protect all key habitats used by focal species throughout their lives within individual marine reserves, or ensure that reserves are close enough to allow focal species to move among habitats. Use compact marine reserves shapes and include whole ecological units.

Establish marine reserves for $>25$ years, preferably permanently, for conservation purposes and to enhance fisheries production.

Seasonal marine reserves can be used to protect focal species during critical life stages.

Address climate change and changes in ocean chemistry, by increasing percent habitat representation, spreading the risk, and increasing protection of key species that increase ecosystem resilience.

Prioritize the protection of coastal habitats that have greater probability of surviving sea level rise.

Prioritize placing marine reserves where there are, or are more likely to be, low levels of threats now and in future.

Diagnose the state of social welfare and manage marine reserves in order to maintain and promote social well-being. Promote community empowerment, social connectivity and positive relationships with stakeholders.

Achieve effective communication to the different educational levels and social groups. All information to be disseminated, must be clear and in accordance with the actors to achieve effective awareness. Ensure that all actors have the same possibilities of receiving the social benefits derived from the marine reserves. 
TABLE 4 | (Continued)

\begin{tabular}{lll}
\hline Category & \\
\cline { 2 - 2 } & Pacific of Baja California Peninsula \\
\hline Considering economic and & Diversify productive activities through financial \\
non-economic uses, and & sustainability. \\
promote an equitable & $\begin{array}{l}\text { Promote sustainable and certified products. } \\
\text { distribution of costs and }\end{array}$ & $\begin{array}{l}\text { Quantify the costs and benefits for the } \\
\text { benefits }\end{array}$ \\
& $\begin{array}{l}\text { design, implementation and management of } \\
\text { marine reserves. }\end{array}$
\end{tabular}

Respecting and maintaining Encourage pride of ownership and consider the cultural identity and diversity perceptions, uses and value that users place on marine resources.

Recognize and document historical knowledge both in the design, implementation and evaluation of marine reserves.
Recognize and respect the diversity of ethnic and cultural groups in the planning and management of marine reserves. Protect and manage sites and resources to protect the cultural roots of users in the area and their sense of identity.
Governance Establishing and ensuring legitimacy and institutional continuity

Implementing collaborative and adaptive management

Promoting effective management
There is a legal framework and shared vision that shapes policies and guides actions at different scales. Actors act with integrity, consistency and transparency.

Guarantee the participation of local people and vulnerable groups, respecting their uses, customs, rights and promoting gender equality.

Promote stakeholder commitment to establish and govern marine reserves.

Have a two-way communication (between the one who generates the information and who receives it) that is timely, pertinent and updated.

Promote adaptive management through the design, implementation and continuation of monitoring. Make continuous analysis and communicate the results and progress of the evaluations.
Gulf of California

Minimize economic costs, maximize the benefits and promote an equitable distribution of costs, benefits and responsibilities in the design and ongoing management of marine reserves. Consider the scope, spatial extent and implications of marine reserves for stakeholders, as well as their uses and rights.
There is a legal framework and shared vision that shapes policies and guides actions at different scales. Actors act with integrity, consistency and transparency.

Develop a network of support organizations that is vertically and horizontally connected and promote good social relations between stakeholders.

Establish a process for monitoring, evaluation, communication and deliberation to promote adaptation and innovation in management processes.

Policies, processes, spaces and structures ensure recognition and respect for the needs and aspirations of the various stakeholders through a co-management process in the identification, deliberation and implementation of different actions.
Mexican Caribbean

Diversify productive activities through financial sustainability.

Minimize economic costs, maximize the benefits and promote an equitable distribution of costs, benefits and responsibilities in the design and ongoing management of marine reserves.

Promote technologies that increase efficiency and sustainability in fisheries management.

Promote market mechanisms that optimize monetary, social and environmental benefits.

Encourage pride of ownership and consider the perceptions, uses and value that users place on marine resources.

Recognize and document historical knowledge in the design, implementation and evaluation of marine reserves.

Include knowledge of the different ethnic groups represented in the area, and of the different generational groups and genders in the community.

There is a legal framework and shared vision that shapes policies and guides actions at different scales. Actors act with integrity, consistency and transparency. Disseminate among stakeholders information about their fundamental rights. Carry out a cross-sectional review of the entire process so that rights are not violated.

Establish a process for monitoring, evaluation, communication and deliberation to promote adaptation and innovation in management processes.

Policies, processes, spaces and structures ensure recognition and respect for the needs and aspirations of the various stakeholders through a co-management process in the identification, deliberation on and implementation of different actions. Enforce laws and regulations impartially and consistently, having capable and competent authorities. Guarantee conservation without damage to third parties.

Ensure that financing is adequate for management and that strategies and activities are efficient.

Establish performance indicators to ensure transparency in decision making and accountability of stakeholders.

Seek the allocation of human and financial resources, as well as the necessary capacities to achieve the objectives of marine reserves and effective management. Ensure that the practice of governance and management of reserves is compatible and coordinated with the plans and policies of other levels of government and sectors of society. 
and governance considerations in marine conservation (Green et al., 2009; Halpern et al., 2013; Mangubhai et al., 2015; Diggon et al., 2019). While we drew inspiration from previous efforts, there have been relatively few processes that developed and applied principles for all three considerations i.e., biophysical, socio-economic and governance (Cornu et al., 2014; Frazão Santos et al., 2018). Thus, we also drew from a broad literature related to biophysical, socio-economic, and governance considerations in marine and environmental design and management to fill gaps (see literature review). Our principles related to biophysical considerations were much more similar to those found elsewhere in the literature, likely because biophysical principles have been more well-developed and applied to other planning processes (Green et al., 2009, 2014; Munguia-Vega et al., 2018a). However, the development and application of socio-economic and governance principles is much more nascent and variable in application (Cornu et al., 2014; Frazão Santos et al., 2018), so the principles we developed in these areas were mostly new and adapted to the local context. During the process of adapting the principles, we realized that in a transboundary context, biophysical principles could generally be adapted equally, while socio-economic and governance principles needed to consider national socioeconomic conditions and legal frameworks.

There were several other substantial differences to processes that we are aware of elsewhere. The first is that the principles were adapted to each of the three regions. The rationale behind this decision is that it will increase legitimacy among local actors, improve fit to the different local biophysical, socio-economic, and governance contexts, and increase the likelihood of both uptake and success. Second, while many sets of principles are intended to just be developed at the planning phase, we developed the principles to be attentive to both the planning and management phases of marine conservation (e.g., some of the socio-economic and governance principles are more related to the design process, while others are broader advice for working with and considering the needs of people). Finally, we intend the principles to be adapted and used at different scales ranging from regional marine design processes, to local community initiatives.

\section{Next Steps to Promote Uptake and Application}

Yet, the process is ongoing. Additional steps are recommended to promote further uptake and application of the principles at various scales, by different groups, and in different regions. Priority activities include the following:

1. Integrating biophysical, social, and governance considerations in legal and policy mandates: The formalization and institutionalization of these biophysical, socio-economic, and governance considerations for marine reserve design within marine conservation and fisheries management laws and policies will encourage their uptake and application. In the case of Mexico, as there are various agencies responsible for marine conservation and fisheries management (i.e., CONANP, INAPESCA, and CONAPESCA), different legal and policy frameworks will need to incorporate this mandate including the LGEEPA (General Law of Ecological Equilibrium and Environmental Protection), which provides the framework for environmental policy and LGPAS (General Law for Sustainable Fisheries and Aquaculture).

2. Adapting the principles for other regions: As the principles were developed through regional processes so that they fit each context, additional processes will be needed to work with key stakeholders to adapt and refine the design criteria for other regions in Mexico (e.g., in the Gulf of Mexico and the southwestern Mexican Pacific). These geographies are relevant for fisheries and for biodiversity conservation, and are locations where marine spatial planning and transboundary fisheries management initiatives are occurring or will occur.

3. Applying the biophysical, socio-economic, and governance principles to design networks of marine reserves and fisheries replenishment areas: Marine reserve network planning processes can take the principles into account during two simultaneous processes: (a) identifying priority areas by conducting spatial prioritizations using the best available information to identify broad areas of ecological importance and (b) working with local stakeholders to consider how their needs, concerns, interests and local knowledge can be taken into account (Margules and Pressey, 2000; Ehler and Douvere, 2009; Green et al., 2014; Mangubhai et al., 2015; Morzaria-Luna et al., 2020a,b). There is also a need to continue to close the gap between biodiversity conservation and fisheries management (Weigel et al., 2014) - by searching for synergies between area-based conservation measures (CONANP) and fisheries management measures, and the value of fish refuges and community reserves (CONAPESCA-INAPESCA) for biodiversity conservation.

4. Employing the principles to guide management activities: Much of the guidance associated with the principles is also intended to be used during management planning and adaptive management. The principles might be, for example, incorporated into the design of the management plans for Natural Protected Areas (CONANP). Management plans for protected areas should be reviewed every 5 years, providing opportunities for adaptive management based on the principles. The inclusion of the design principles in the NOM-049 and the practice of establishing fish refuges for predetermined time periods (e.g., 5 years) both provide opportunities for adaptive management during the renewal of fish refuges (CONAPESCA). Short and long term financial support needs to be in place to promote effective and adaptive management.

5. Creating accessible databases of biophysical and socioeconomic information: An important enabler for evidence informed marine planning and management processes is the collation of available data into accessible and shareable databases that includes both ecological and socio-economic information. This process of gathering and collation can also help to identify information gaps 
and research needs. Maintaining a centralized and openaccess repository for this information will ensure that it can be used by stakeholders, governmental and nongovernmental planners, and by the scientific community (Palacios-Abrantes et al., 2019).

6. Measuring progress through ongoing monitoring and evaluation: The principles are essentially an ideal set of criteria, and as such can be used to develop indicators for each aspect to establish a baseline and monitor progress. These insights can be used to inform and improve designs and effectiveness through adaptive management. Indicators might be developed to be applied at various scales (e.g., a region or an individual initiative) and to different types of marine conservation initiatives (e.g., MPAs, fish refuges, community areas). For example, indicators might be developed such that communities can do the monitoring themselves and communicated (Fulton et al., 2019; González-Cuellar et al., 2019).

7. Using the principles as the basis of community workshops and deliberations: Building on the examples above, communities might refer to the principles during the design or renewal processes of their locally conserved areas. Areas prioritized through science driven processes that align with the principles can be brought to fishing cooperatives or communities for refinement through stakeholder deliberations and feedback. Monitoring of the impacts and effectiveness is a key part of the reserve renewal process, which might be carried out in partnership with researchers based on community-selected indicators (and collaborating with them to do part of the monitoring, e.g., fisheries monitoring).

8. Ensuring that principles stay relevant over time: All environmental policies should be viewed as experiments. Thus, it will be important to consider the principles as being fluid and adaptive, not rigid and prescriptive. As new knowledge emerges and additional learning occurs, the principles should be revisited periodically and adapted as necessary. For example, adaptations may need to be made to better account for transboundary planning, marine heatwaves and prioritize the connectivity of climate-refuge habitats.

\section{Lessons Learned From the Process}

Finally, we provide some thoughts on lessons that we learned for others engaging in similar processes elsewhere. First, the process of development is as important as the final product for building legitimacy, support, and alignment around a common goal. Key ingredients included stakeholder participation, coordination across agencies and organizations, regionalization of the processes, and skilled facilitation. Broad and effective stakeholder involvement requires identifying and mapping stakeholders, selecting representatives of different groups to invite, and ensuring a balance of genders and underrepresented groups (e.g., small-scale fishers, Indigenous groups) are included. It is important to recognize that some groups may not have equal opportunities or abilities to participate, due to temporal or financial constraints, so special arrangements may need to be made to enable their participation. Bringing together government agencies with non-governmental organizations in the process required negotiation and respectful listening from participants and facilitators to ensure everyone's needs and interests were addressed, which allowed the development of strong partnerships and the construction of a common language that can be applied across jurisdictions and to different types of marine reserves. Conducting separate processes in each region allowed for adaptation of the principles to different biophysical, socio-economic, and governance contexts and increased local legitimacy and support for the process and outputs. Skilled facilitation - including in the design of workshops and the creation of a space where all voices and perspectives are valued - also enabled a good process and outputs. We found it particularly important to take the time to listen to stakeholders on terminology and on concerns regarding the models of fisheries management and conservation that are implied. In our process, for example, we had a robust debate on the pros and cons of fish refuges versus other types of marine protected areas, considering the opinion of fishers, cooperatives and government agencies.

Second, the quality of the product requires a strong basis in science, interdisciplinary and transdisciplinary expertise, and attention to various applications across phases. The principles were developed based on the best available evidence from both the natural and social sciences, as well as local and practitioner knowledge. This bridging of knowledge types required strong interdisciplinary and transdisciplinary engagements with experts from different disciplines and with field experience. Different disciplinary expertise was needed, for example, to help the group to understand ideas related to key habitats and species, connectivity, climate change, human well-being, economics, culture, or governance. In addition it was important to have the expertise of practitioners in the process to help articulate how each topic and principle could be defined and applied. Unlike in some processes, we found that the principles and guidance would be most useful if designed to be applicable to both planning and management stages. This meant that some were spatially explicit, in order to help identify priority areas for marine conservation, while others were more focused on engagement processes or management activities.

Third, it is a long-term process to move from starting the project to implementation. Thus, carrying out the work requires a strong and long-term vision, a committed team, capable leadership, adequate financial resources for each stage of the process and intersectoral coordination and government engagement. After the initial period of project development and fundraising, developing the principles through participatory workshops with stakeholders alone took 1-2 years in each location. The scientific and technical work to develop marine reserve networks can take much longer. Additional time and efforts were also needed to support uptake and application of the principles through communication, outreach, advocacy and working with stakeholders. A key remaining challenge in this process is the time it will take to continue to promote, facilitate and track implementation of the principles. Long time frames and follow-up will be needed to ensure principles are applied and benefits emerge from the marine conservation 
initiatives. However, the results are very valuable, and the effort is worthwhile.

\section{CONCLUSION}

We are beginning a critical decade for fisheries management and marine conservation. The approach and actions that we take today will shape the future of marine biodiversity, fisheries management, and people's relationship with the ocean. This paper reviews the results of a participatory process to coproduce principles to guide marine conservation design and management across three different geographies in Mexico. The biophysical, socio-economic, and governance principles provide a roadmap for a holistic approach to marine conservation and fisheries management in the country. We hope the process and principles we have examined in this paper will be applied as networks of marine reserves and scaled up within Mexico and through transboundary initiatives with neighboring countries. The process and principles might also be instructive for marine conservation occurring elsewhere. Adopting a holistic approach to marine conservation and management will help to achieve a future where people and oceans can thrive together.

\section{AUTHOR CONTRIBUTIONS}

MP-d, NB, SF, AM-V, CL-T, MW-M, JZ-D, EF, and AG contributed to conceptualization. MP-d, NB, and SF contributed

\section{REFERENCES}

Abe, J., Brown, B., Ajao, E. A., and Donkor, S. (2016). Local to regional polycentric levels of governance of the Guinea Current Large Marine Ecosystem. Environ. Dev. 17, 287-295. doi: 10.1016/j.envdev.2015.06.006

Alexander, K. A., Hobday, A. J., Cvitanovic, C., Ogier, E., Nash, K. L., Cottrell, R. S., et al. (2018). Progress in integrating natural and social science in marine ecosystem-based management research. Mar. Freshw. Res. 70, 71-83. doi: 10. 1071/MF17248

Álvarez-Romero, J. G., Munguía-Vega, A., Beger, M., Del Mar Mancha-Cisneros, M., Suárez-Castillo, A. N., Gurney, G. G., et al. (2018). Designing connected marine reserves in the face of global warming. Glob. Change Biol. 24, e671-e691. doi: $10.1111 /$ gcb.13989

Anderies, J. M., and Janssen, M. A. (2013). Robustness of social-ecological systems: implications for public policy. Policy Stud. J. 41, 513-536. doi: 10.1111/psj. 12027

Anderson, J. L., Anderson, C. M., Chu, J., Meredith, J., Asche, F., Sylvia, G., et al. (2015). The fishery performance indicators: a management tool for triple bottom line outcomes. PLoS One 10:e0122809. doi: 10.1371/journal.pone. 0122809

Anderson, L. G., and Seijo, J. C. (2011). Bioeconomics of Fisheries Management. Hoboken, NJ: John Wiley \& Sons.

Arafeh-Dalmau, N., Cavanaugh, K. C., Possingham, H. P., Munguia-Vega, A., Montaño-Moctezuma, G., Bell, T. W., et al. (2021). Southward decrease in the protection of persistent giant kelp forests in the northeast Pacific. Commun. Earth Environ. 2, 1-7. doi: 10.1038/s43247-021-00177-9

Arafeh-Dalmau, N., Torres-Moye, G., Seingier, G., Montaño-Moctezuma, G., and Micheli, F. (2017). Marine spatial planning in a transboundary context: linking Baja California with California's network of marine protected areas. Front. Mar. Sci. 4:150. doi: 10.3389/fmars.2017.00150

Armitage, D. (2005). Adaptive capacity and community-based natural resource management. Environ. Manage. 35, 703-715. doi: 10.1007/s00267-004-0076-z to writing - original draft. AS, AW, AF, AV, CZ, CM, DF, FM, HR-B, IC, IL-E, JT, LV-V, MG-R, MM-C, ME-R, MM, NA-D, $\mathrm{OG}-\mathrm{C}, \mathrm{OH}$, and $\mathrm{SR}$ contributed to writing - review and editing. MP-d, NB, SF, AM-V, CL-T, MW-M, JZ-D, EF, AG, AS, AW, AF, AV, CZ, CM, DF, FM, HR-B, IC, IL-E, JT, LV-V, MG-R, MM-C, ME-R, MM, NA-D, OG-C, OH, and SR contributed to participation in workshops. All authors contributed to the article and approved the submitted version.

\section{FUNDING}

We would like to acknowledge the financial support of the following contributors for the creation of the design principles in the three regions: The Walton Family Foundation, Fundación Televisa, David and Lucile Packard Foundation, The Marisla Foundation, MAR Fund, Fundación Claudia y Roberto Hernández, Fundación Alfredo Harp Helú, The Summit Foundation, Oceans 5, Sandler Foundation, Andrew and Jennifer Duerkop, and anonymous donors to The Nature Conservancy.

\section{ACKNOWLEDGMENTS}

We are incredibly appreciative of the time and input of all participants in the participatory workshops in all three regions of Mexico.

Armitage, D., Berkes, F., and Doubleday, N. (2010). Adaptive Co-Management: Collaboration, Learning, and Multi-Level Governance. Vancouver, BC: UBC Press.

Armitage, D., de Loë, R., and Plummer, R. (2012). Environmental governance and its implications for conservation practice. Conserv. Lett. 5, 245-255. doi: 10.1111/j.1755-263X.2012.00238.x

Armitage, D., and Plummer, R. (2011). Adaptive Capacity and Environmental Governance. Berlin: Springer.

Aswani, S. (2017). Customary management as TURFs: social challenges and opportunities. Bull. Mar. Sci. 93, 3-12. doi: 10.5343/bms.2015.1084

Aswani, S., Basurto, X., Ferse, S., Glaser, M., Campbell, L., Cinner, J. E., et al. (2017). Marine resource management and conservation in the Anthropocene. Environ. Conserv. 45, 192-120. doi: 10.1017/S037689291700 0431

Aswani, S., and Lauer, M. (2006). Incorporating fishermen's local knowledge and behavior into geographical information systems (GIS) for designing marine protected areas in Oceania. Hum. Organ. 65, 81-102.

Baker-Médard, M. (2017). Gendering marine conservation: the politics of marine protected areas and fisheries access. Soc. Nat. Resour. 30, 723-737. doi: 10.1080/ 08941920.2016.1257078

Ball, I. R., Possingham, H. P., and Watts, M. E. (2009). "Marxan and relatives: software for spatial conservation prioritization," in Spatial Conservation Prioritization: Quantitative Methods and Computational Tools, eds A. Moilanen, K. A. Wilson, and H. P. Possingham (Oxford: Oxford University Press), 185-195. doi: 10.1371/journal.pone.0182396

Ban, N. C., Alidina, H. M., and Ardron, J. A. (2010). Cumulative impact mapping: advances, relevance and limitations to marine management and conservation, using Canada's Pacific waters as a case study. Mar. Policy 34, 876-886. doi: 10.1016/j.marpol.2010.01.010

Ban, N. C., Gurney, G. G., Marshall, N. A., Whitney, C. K., Mills, M., Gelcich, S., et al. (2019). Well-being outcomes of marine protected areas. Nat. Sustain. 2:524. doi: 10.1038/s41893-019-0306-2 
Ban, N. C., Mills, M., Tam, J., Hicks, C. C., Klain, S., Stoeckl, N., et al. (2013). A social-ecological approach to conservation planning: embedding social considerations. Front. Ecol. Environ. 11, 194-202. doi: 10.1890/110205

Barnes, M. L., Lynham, J., Kalberg, K., and Leung, P. (2016). Social networks and environmental outcomes. Proc. Natl. Acad. Sci. U.S.A. 113, 6466-6471. doi: 10.1073 /pnas. 1523245113

Bennett, N. J., Dearden, P., Murray, G., and Kadfak, A. (2014). The capacity to adapt?: Communities in a changing climate, environment, and economy on the northern Andaman coast of Thailand. Ecol. Soc. 19:5. doi: 10.5751/ES-06315190205

Bennett, N. J., Franco, A. D., Calò, A., Nethery, E., Niccolini, F., Milazzo, M., et al. (2019). Local support for conservation is associated with perceptions of good governance, social impacts, and ecological effectiveness. Conserv. Lett. 12:e12640. doi: $10.1111 /$ conl.12640

Bennett, N. J., Lasch-Thaler, C., Mancha-Cisneros, M. M., Suárez-Castillo, A. N., Walther-Mendoza, M., Vázquez-Vera, L., et al. (2017a). Integración de Consideraciones Socio-Económicas y de Gobernanza en el Diseño y Manejo de las Zonas de Recuperación en el Golfo de California, México. La Paz, MX: The Nature Conservancy/Comunidad y Biodiversidad A.C.

Bennett, N. J., Teh, L., Ota, Y., Christie, P., Ayers, A., Day, J. C., et al. (2017b). An appeal for a code of conduct for marine conservation. Mar. Policy 81, 411-418. doi: 10.1016/j.marpol.2017.03.035

Bennett, N. J., and Satterfield, T. (2018). Environmental governance: a practical framework to guide design, evaluation, and analysis. Conserv. Lett. 11:e12600. doi: $10.1111 /$ conl.12600

Berkes, F., and Turner, N. (2006). Knowledge, learning and the evolution of conservation practice for social-ecological system resilience. Hum. Ecol. 34, 479-494. doi: 10.1007/s10745-006-9008-2

Berkström, C., Eggertsen, L., Goodell, W., Cordeiro, C. A. M. M., Lucena, M. B., Gustafsson, R., et al. (2020). Thresholds in seascape connectivity: the spatial arrangement of nursery habitats structure fish communities on nearby reefs. Ecography 43, 882-896. doi: 10.1111/ecog.04868

Bezaury-Creel, J. E. (2005). Protected areas and coastal and ocean management in México. Ocean Coast. Manag. 48, 1016-1046. doi: 10.1016/j.ocecoaman.2005. 03.004

Biedenweg, K., Hanein, A., Nelson, K., Stiles, K., Wellman, K., Horowitz, J., et al. (2014). Developing human wellbeing indicators in the puget sound: focusing on the watershed scale. Coast. Manag. 42, 374-390. doi: 10.1080/08920753.2014. 923136

Biedenweg, K., Stiles, K., and Wellman, K. (2016). A holistic framework for identifying human wellbeing indicators for marine policy. Mar. Policy 64, 31-37. doi: 10.1016/j.marpol.2015.11.002

Blake, D., Augé, A. A., and Sherren, K. (2017). Participatory mapping to elicit cultural coastal values for marine spatial planning in a remote archipelago. Ocean Coast. Manag. 148, 195-203. doi: 10.1016/j.ocecoaman.2017.08.010

Bodin, Ö (2017). Collaborative environmental governance: achieving collective action in social-ecological systems. Science 357:eaan1114. doi: 10.1126/science. aan 1114

Bohunovsky, L., Jäger, J., and Omann, I. (2010). Participatory scenario development for integrated sustainability assessment. Reg. Environ. Change 11, 271-284. doi: 10.1007/s10113-010-0143-3

Bonilla, S. (2019). Principios Socioeconómicos y de Gobernanza para el Diseño de una Red de Zonas De Recuperación Pesquera en Honduras. La Ceiba: Centro de Estudios Marinos, MARfund, AK Foundation.

Borrini-Feyerabend, G., Dudley, N., Jaeger, T., Lassen, B., Pathak Broome, N., Philips, A., et al. (2013). Governance of Protected Areas: From Understanding to Action. Gland: IUCN.

Borrini-Feyerabend, G., and Hill, R. (2015). "Governance for the conservation of nature," in Protected Area Governance and Management, eds G. L. Worboys, M. Lockwood, A. Kothari, S. Feary, and I. Pulsford (Canberra, ACT: ANU Press), 169-206.

Borrini-Feyerabend, G., Pimbert, M., Farvar, M. T., Kothari, A., and Renard, Y. (2007). Sharing Power: Learning-by-Doing in Co-Management of Natural Resources Throughout the World. London: Earthscan.

Boyd, E., Nykvist, B., Borgström, S., and Stacewicz, I. A. (2015). Anticipatory governance for social-ecological resilience. AMBIO 44, 149-161. doi: 10.1007/ s13280-014-0604-x
Carlisle, K., and Gruby, R. L. (2017). Polycentric systems of governance: a theoretical model for the commons. Policy Stud. J. 47, 927-952. doi: 10.1111/ psj. 12212

Chaffin, B. C., Garmestani, A. S., Gunderson, L. H., Benson, M. H., Angeler, D. G., Arnold, C. A. (Tony), et al. (2016). Transformative environmental governance. Annu. Rev. Environ. Resour. 41, 399-423. doi: 10.1146/annurev-environ110615-085817

Charnley, S., Carothers, C., Satterfield, T., Levine, A., Poe, M. R., Norman, K., et al. (2017). Evaluating the best available social science for natural resource management decision-making. Environ. Sci. Policy 73, 80-88. doi: 10.1016/j. envsci.2017.04.002

Chollett, I., Garavelli, L., Holstein, D., Cherubin, L., Fulton, S., and Box, S. J. (2017). A case for redefining the boundaries of the Mesoamerican Reef Ecoregion. Coral Reefs 36, 1039-1046. doi: 10.1007/s00338-017-1595-4

Chollett, I., Mumby, P. J., Müller-Karger, F. E., and Hu, C. (2012). Physical environments of the Caribbean Sea. Limnol. Oceanogr. 57, 1233-1244. doi: 10.4319/lo.2012.57.4.1233

Cicin-Sain, B., and Belfiore, S. (2005). Linking marine protected areas to integrated coastal and ocean management: a review of theory and practice. Ocean Coast. Manag. 48, 847-868. doi: 10.1016/j.ocecoaman.2006.01.001

Cinner, J. E., Maire, E., Huchery, C., MacNeil, M. A., Graham, N. A. J., Mora, C., et al. (2018b). Gravity of human impacts mediates coral reef conservation gains. Proc. Natl. Acad. Sci. U.S.A. 115, E6116-E6125. doi: 10.1073/pnas.1708001115

Cinner, J. E., Adger, W. N., Allison, E. H., Barnes, M. L., Brown, K., Cohen, P. J., et al. (2018a). Building adaptive capacity to climate change in tropical coastal communities. Nat. Clim. Change 8, 117-123. doi: 10.1038/s41558-017065-x

Cinner, J. E., and Aswani, S. (2007). Integrating customary management into marine conservation. Biol. Conserv. 140, 201-216. doi: 10.1016/j.biocon.2007. 08.008

Cisneros-Mata, M. A. (2010). "The importance of fisheries in the Gulf of California and ecosystem-based sustainable co-management for conservation," in The Gulf of California: Biodiversity and Conservation, ed. R. C. Brusca (Tucson, AZ: University of Arizona Press), 119-134.

COBI, and TNC (2019a). Adaptación de Principios Socioeconómicos y de Gobernanza para el Diseño y Manejo Efectivo de Zonas de Recuperación en el Caribe Mexicano. Mexico, CDMX: Comunidad y Biodiversidad, A.C. y The Nature Conservancy.

COBI, and TNC (2019b). Identificación y Adaptación de Principios de Gobernanza y Socioeconómicos para el Diseño y Manejo Efectivo de Zonas de Recuperación en la Región Pacífico de la Península de Baja California. Mexico, CDMX: Comunidad y Biodiversidad, A.C. y The Nature Conservancy.

Cohen, P. J., Evans, L. S., and Mills, M. (2012). Social networks supporting governance of coastal ecosystems in Solomon Islands. Conserv. Lett. 5, 376-386. doi: 10.1111/j.1755-263X.2012.00255.x

CONANP (2020). LISTANP Listado de las Áreas Naturales Protegidas, CONANP, Gobierno de Mexico. Available online at: http://sig.conanp.gob.mx/website/ pagsig/listanp/ (accessed November 19, 2020).

CONAPESCA (2019). Zonas de Refugio Pesquero Vigentes en Mexico al 11 de Diciemgbre de 2019. Mexico, CDMX: Comisión Nacional de Acuacultura y Pesca, Gobierno de Mexico.

Cooke, S. J., Nguyen, V. M., Chapman, J. M., Reid, A. J., Landsman, S. J., Young, N., et al. (2020). Knowledge co-production: a pathway to effective fisheries management, conservation, and governance. Fisheries 46, 89-97. doi: 10.1002/ fsh. 10512

Cornu, E. L., Kittinger, J. N., Koehn, J. Z., Finkbeiner, E. M., and Crowder, L. B. (2014). Current practice and future prospects for social data in coastal and ocean planning. Conserv. Biol. 28, 902-911. doi: 10.1111/cobi.12310

Cumming, G. S., and Allen, C. R. (2017). Protected areas as social-ecological systems: perspectives from resilience and social-ecological systems theory. Ecol. Appl. 27, 1709-1717. doi: 10.1002/eap.1584

Dahlke, F. T., Wohlrab, S., Butzin, M., and Pörtner, H.-O. (2020). Thermal bottlenecks in the life cycle define climate vulnerability of fish. Science 369, 65-70. doi: 10.1126/science.aaz3658

Dalton, T., Forrester, G., and Pollnac, R. (2012). Participation, process quality, and performance of marine protected areas in the wider Caribbean. Environ. Manag. 49, 1224-1237. doi: 10.1007/s00267-012-9855-0 
d'Armengol, L., Prieto Castillo, M., Ruiz-Mallén, I., and Corbera, E. (2018). A systematic review of co-managed small-scale fisheries: social diversity and adaptive management improve outcomes. Glob. Environ. Change 52, 212-225. doi: 10.1016/j.gloenvcha.2018. 07.009

Diedrich, A., Stoeckl, N., Gurney, G. G., Esparon, M., and Pollnac, R. (2017). Social capital as a key determinant of perceived benefits of community-based marine protected areas: social capital and MPAs. Conserv. Biol. 31, 311-321. doi: $10.1111 /$ cobi. 12808

Dietz, T., Ostrom, E., and Stern, P. C. (2003). The struggle to govern the commons. Science 302, 1907-1912. doi: 10.1126/science.1091015

Diggon, S., Butler, C., Heidt, A., Bones, J., Jones, R., and Outhet, C. (2019). The marine plan partnership: indigenous community-based marine spatial planning. Mar. Policy 132:103510. doi: 10.1016/j.marpol.2019.04.014

Djenontin, I. N. S., and Meadow, A. M. (2018). The art of co-production of knowledge in environmental sciences and management: lessons from international practice. Environ. Manag. 61, 885-903. doi: 10.1007/s00267-0181028-3

Domínguez-Tejo, E., Metternicht, G., Johnston, E., and Hedge, L. (2016). Marine spatial planning advancing the ecosystem-based approach to coastal zone management: a review. Mar. Policy 72, 115-130. doi: 10.1016/j.marpol.2016. 06.023

Drew, J. A. (2005). Use of traditional ecological knowledge in marine conservation. Conserv. Biol. 19, 1286-1293. doi: 10.1111/j.1523-1739.2005.00158.x

Duarte, C. M., Agusti, S., Barbier, E., Britten, G. L., Castilla, J. C., Gattuso, J.-P., et al. (2020). Rebuilding marine life. Nature 580, 39-51. doi: 10.1038/s41586020-2146-7

Dunn, D. C., Harrison, A.-L., Curtice, C., DeLand, S., Donnelly, B., Fujioka, E., et al. (2019). The importance of migratory connectivity for global ocean policy. Proc. R. Soc. B Biol. Sci. 286:20191472. doi: 10.1098/rspb.2019.1472

Durazo, R., and Baumgartner, T. R. (2002). Evolution of oceanographic conditions off Baja California: 1997-1999. Prog. Oceanogr. 54, 7-31. doi: 10.1016/S00796611(02)00041-1

Edgar, G. J., Stuart-Smith, R. D., Willis, T. J., Kininmonth, S., Baker, S. C., Banks, S., et al. (2014). Global conservation outcomes depend on marine protected areas with five key features. Nature 506, 216-220. doi: 10.1038/nature13022

Ehler, C., and Douvere, F. (2009). Marine Spatial Planning: A Step-by-Step Approach Towards Ecosystem-Based Management. Paris: Intergovernmental Oceanographic Commission and Man and the Biosphere Programme.

Emerton, L., Bishop, J., and Thomas, L. (2006). Sustainable Financing of Protected Areas: A Global Review of Challenges and Options. Gland: IUCN.

Erisman, B., Heyman, W., Kobara, S., Ezer, T., Pittman, S., Aburto-Oropeza, O., et al. (2017). Fish spawning aggregations: where well-placed management actions can yield big benefits for fisheries and conservation. Fish Fish. 18, 128-144. doi: $10.1111 /$ faf.12132

Erisman, B. E., Paredes, G. A., Plomozo-Lugo, T., Cota-Nieto, J. J., Hastings, P. A., and Aburto-Oropeza, O. (2011). Spatial structure of commercial marine fisheries in Northwest Mexico. ICES J. Mar. Sci. 68, 564-571. doi: 10.1093/ icesjms/fsq179

Espinosa-Andrade, N. (2019a). Evaluación de las Zonas de Recuperación de la Región Pacífico de la Península de Baja California con Base en los Principios Biofísicos de Diseño. Guaymas, MX: Comunidad y Biodiversidad, A.C.

Espinosa-Andrade, N. (2019b). Evaluación de las Zonas de Recuperación del Golfo de California con Base en los Principios Biofísicos de Diseño. Guaymas, MX: Comunidad y Biodiversidad, A.C.

Espinosa-Andrade, N. (2019c). Evaluación de las Zonas de Recuperación del Sistema Arrecifal Mesoamericano en México (SAM-México) con Base en los Principios Biofísicos de Diseño. Guaymas, MX: Comunidad y Biodiversidad, A.C.

Espinosa-Andrade, N., Suchley, A., Reyes-Bonilla, H., and Alvarez-Filip, L. (2020). The no-take zone network of the Mexican Caribbean: assessing design and management for the protection of coral reef fish communities. Biodivers. Conserv. 29, 2069-2087. doi: 10.1007/s10531-020-0 1966-y

Espinosa-Romero, M. J., Chan, K. M. A., McDaniels, T., and Dalmer, D. M. (2011). Structuring decision-making for ecosystem-based management. Mar. Policy 35, 575-583. doi: 10.1016/j.marpol.2011.01.019

Ezcurra, E., Aburto-Oropeza, O., de los Angeles Cavajal, M., Cudney-Bueno, R., and Torre, J. (2009). "Gulf of California, Mexico," in Ecosystem-Based
Management for the Oceans, eds K. McLeod and H. Leslie (Washington, DC: Island Press), 227-252.

Fernandes, L., Day, J., Lewis, A., Slegers, S., Kerrigan, B., Breen, D., et al. (2005). Establishing representative no-take areas in the Great Barrier Reef: largescale implementation of theory on marine protected areas. Conserv. Biol. 19, 1733-1744. doi: 10.1111/j.1523-1739.2005.00302.x

Finkbeiner, E. M. (2015). The role of diversification in dynamic small-scale fisheries: lessons from Baja California Sur, Mexico. Glob. Environ. Change 32, 139-152. doi: 10.1016/j.gloenvcha.2015.03.009

Folke, C., Hahn, T., Olsson, P., and Norberg, J. (2005). Adaptive governance of social-ecological systems. Annu. Rev. Environ. Resour. 30, 441-473. doi: 10. 1146/annurev.energy.30.050504.144511

Frazão Santos, C., Agardy, T., Andrade, F., Crowder, L. B., Ehler, C. N., and Orbach, M. K. (2018). Major challenges in developing marine spatial planning. Mar. Policy 132:103248. doi: 10.1016/j.marpol.2018.08.032

Frazão Santos, C., Ehler, C. N., Agardy, T., Andrade, F., Orbach, M. K., and Crowder, L. B. (2019). "Marine spatial planning," in World Seas: An Environmental Evaluation, ed. C. Sheppard (Cambridge, MA: Academic Press), 571-592. doi: 10.1016/B978-0-12-805052-1.00033-4

Fulton, S., Hernández-Velasco, A., Suarez-Castillo, A., Fernández-Rivera Melo, F., Rojo, M., Sáenz-Arroyo, A., et al. (2019). "From fishing fish to fishing data: the role of artisanal fishers in conservation and resource management in Mexico," in Viability and Sustainability of Small-Scale Fisheries in Latin America and The Caribbean MARE Publication Series, eds S. Salas, M. J. Barragán-Paladines, and R. Chuenpagdee (Cham: Springer International Publishing), 151-175. doi: 10.1007/978-3-319-76078-0_7

Gaines, S. D., White, C., Carr, M. H., and Palumbi, S. R. (2010). Designing marine reserve networks for both conservation and fisheries management. Proc. Natl. Acad. Sci. U.S.A. 107, 18286-18293. doi: 10.1073/pnas.0906473107

Garcia, S. M. (2003). The Ecosystem Approach to Fisheries: Issues, Terminology, Principles, Institutional Foundations, Implementation and Outlook. Rome: Food and Agriculture Organization.

Gaymer, C. F., Stadel, A. V., Ban, N. C., Cárcamo, P. F., Ierna, J., and Lieberknecht, L. M. (2014). Merging top-down and bottom-up approaches in marine protected areas planning: experiences from around the globe. Aquat. Conserv. Mar. Freshw. Ecosyst. 24, 128-144. doi: 10.1002/aqc.2508

Gee, K., Kannen, A., Adlam, R., Brooks, C., Chapman, M., Cormier, R., et al. (2017). Identifying culturally significant areas for marine spatial planning. Ocean Coast. Manag. 136, 139-147. doi: 10.1016/j.ocecoaman.2016.11.026

Gell, F. R., and Roberts, C. M. (2003). Benefits beyond boundaries: the fishery effects of marine reserves. Trends Ecol. Evol. 18, 448-455. doi: 10.1016/S01695347(03)00189-7

Gilani, H. R., Innes, J. L., and Kent, H. (2018). Developing human well-being domains, metrics and indicators in an ecosystem-based management context in Haida Gwaii, British Columbia, Canada. Soc. Nat. Resour. 31, 1321-1337. doi: 10.1080/08941920.2018.1481548

Gill, D. A., Mascia, M. B., Ahmadia, G. N., Glew, L., Lester, S. E., Barnes, M., et al. (2017). Capacity shortfalls hinder the performance of marine protected areas globally. Nature 543, 665-669. doi: 10.1038/nature21708

Gollan, N., Voyer, M., Jordan, A., and Barclay, K. (2019). Maximising community wellbeing: assessing the threats to the benefits communities derive from the marine estate. Ocean Coast. Manag. 168, 12-21. doi: 10.1016/j.ocecoaman.2018. 10.020

González-Cuellar, O. T., Weaver, A. H., Rodríguez-Villalobos, J. C., and LópezSagástegui, C. (2019). Evaluación de Zonas de Refugio Pesquero del Corredor San Cosme a Punta Coyote. FOR: Sociedad de Historia Natural Niparajá, A. C. 2019. Evalución de Zonas de Refugio Pesquero del Corredor San Cosme a PuntaCoyote-Resultados biológicos y ecológicos del monitoreo submarino 2012-2018. Niparajá, A.C: La Paz, México.

Green, A., Chollett, I., Suárez, A., Dahlgren, C., Cruz, S., Zepeda, C., et al. (2017). Biophysical Principles for Designing a Network of Replenishment Zones for the Mesoamerican Reef System. The Nature Conservancy, Comunidad y Biodiversidad, A.C., Smithsonian Institution, Perry Institute for Marine Science, Centro de Estudios Marinos, Healthy Reefs Initiative and Universidad Autónoma de Baja California Sur: Cancún, México.

Green, A., Smith, S. E., Lipsett-Moore, G., Groves, C., Peterson, N., Sheppard, S., et al. (2009). Designing a resilient network of marine protected areas for Kimbe Bay, Papua New Guinea. Oryx 43, 488-498. doi: 10.1017/S0030605309990342 
Green, A. L., Fernandes, L., Almany, G., Abesamis, R., McLeod, E., Aliño, P. M., et al. (2014). Designing marine reserves for fisheries management, biodiversity conservation, and climate change adaptation. Coast. Manag. 42, 143-159. doi: 10.1080/08920753.2014.877763

Green, A. L., Maypa, A. P., Almany, G. R., Rhodes, K. L., Weeks, R., Abesamis, R. A., et al. (2015). Larval dispersal and movement patterns of coral reef fishes, and implications for marine reserve network design. Biol. Rev. 90, 1215-1247. doi: $10.1111 /$ brv. 12155

Grimmel, H., Calado, H., Fonseca, C., and Suárez de Vivero, J. L. (2019). Integration of the social dimension into marine spatial planning - theoretical aspects and recommendations. Ocean Coast. Manag. 173, 139-147. doi: 10. 1016/j.ocecoaman.2019.02.013

Guerrero, A. M., and Wilson, K. A. (2016). Using a social-ecological framework to inform the implementation of conservation plans. Conserv. Biol. 31, 290-301. doi: $10.1111 /$ cobi. 12832

Gunton, T., Rutherford, M., and Dickinson, M. (2010). Stakeholder analysis in marine planning. Environ. J. Interdiscip. Stud. 37, 95-110.

Gurney, G. G., Pressey, R. L., Ban, N. C., Alvarez-Romero, J. G., Jupiter, S., and Adams, V. M. (2015). Efficient and equitable design of marine protected areas in Fiji through inclusion of stakeholder-specific objectives in conservation planning. Conserv. Biol. 29, 1378-1389. doi: 10.1111/cobi. 12514

Halpern, B. S., Frazier, M., Afflerbach, J., Lowndes, J. S., Micheli, F., O’Hara, C., et al. (2019). Recent pace of change in human impact on the world's ocean. Sci. Rep. 9:11609 . doi: 10.1038/s41598-019-47201-9

Halpern, B. S., Klein, C. J., Brown, C. J., Beger, M., Grantham, H. S., Mangubhai, S., et al. (2013). Achieving the triple bottom line in the face of inherent trade-offs among social equity, economic return, and conservation. Proc. Natl. Acad. Sci. U.S.A. 110, 6229-6234. doi: 10.1073/pnas.1217689110

Harvey, B., Cochrane, L., and Epp, M. V. (2019). Charting knowledge coproduction pathways in climate and development. Environ. Policy Gov. 29, 107-117. doi: 10.1002/eet.1834

Havard, L., Brigand, L., and Cariño, M. (2015). Stakeholder participation in decision-making processes for marine and coastal protected areas: case studies of the south-western Gulf of California, Mexico. Ocean Coast. Manag. 116, 116-131. doi: 10.1016/j.ocecoaman.2015.06.017

Hobday, A., Ogier, E., Fleming, A., Hartog, J., Thomas, L., Ilona, S., et al. (2016). Fishery Status Report: Healthcheck for Australian Fisheries. Hobart, TAS: CSIRO Oceans and Atmosphere.

Hobday, A. J., Fleming, A., Ogier, E. M., Thomas, L., Hartog, J. R., Hornborg, S., et al. (2018). Perceptions regarding the need for broad sustainability assessments of Australian fisheries. Fish. Res. 208, 247-257. doi: 10.1016/j. fishres.2018.08.006

INEGI (2020). Número de Habitantes. Quintana Roo. Censo Poblac. Vivienda. Available online at: http://cuentame.inegi.org.mx/monografias/informacion/ QRoo/Poblacion/ (accessed April 29, 2021).

Ison, S., Hills, J., Morris, C., and Stead, S. M. (2018). Sustainable financing of a national marine protected area network in Fiji. Ocean Coast. Manag. 163, 352-363. doi: 10.1016/j.ocecoaman.2018.07.011

Jonas, H., Makagon, J., and Roe, D. (2016). Conservation Standards: From Rights to Responsibilities. London: International Institute for Environment and Development.

Kaplan-Hallam, M., and Bennett, N. J. (2018). Adaptive social impact management for conservation and environmental management. Conserv. Biol. 32, 304-314. doi: $10.1111 /$ cobi. 12985

Karrasch, L., Maier, M., Kleyer, M., and Klenke, T. (2017). Collaborative landscape planning: co-design of ecosystem-based land management scenarios. Sustainability 9:1668. doi: 10.3390/su9091668

Kittinger, J. N., Koehn, J. Z., Le Cornu, E., Ban, N. C., Gopnik, M., Armsby, M., et al. (2014). A practical approach for putting people in ecosystembased ocean planning. Front. Ecol. Environ. 12, 448-456. doi: 10.1890/1 30267

Klain, S. C., and Chan, K. M. A. (2012). Navigating coastal values: participatory mapping of ecosystem services for spatial planning. Ecol. Econ. 82, 104-113. doi: 10.1016/j.ecolecon.2012.07.008

Kleiber, D., Harris, L., and Vincent, A. C. J. (2018). Gender and marine protected areas: a case study of Danajon Bank, Philippines. Marit. Stud. 17, 163-175. doi: $10.1007 /$ s40152-018-0107-7
Klein, C. J., Brown, C. J., Halpern, B. S., Segan, D. B., McGowan, J., Beger, M., et al. (2015). Shortfalls in the global protected area network at representing marine biodiversity. Sci. Rep. 5:17539. doi: 10.1038/srep17539

Koch, V. (2015). Analisis Comparativo de Instrumentos para la Conservacion y el Uso Sustentable de la Biodiversidad en el Golfo de California. Bonn: Alemania: Deutsche Gesellschaft für Internationale Zusammenarbeit (GIZ).

Kockel, A., Ban, N. C., Costa, M., and Dearden, P. (2019). Evaluating approaches for scaling up community-based marine protected areas into socially equitable and ecologically representative networks. Conserv. Biol. 34, 137-147. doi: 10. 1111/cobi.13368

Kramer, P., McField, M., Álvarez-Filip, L., Drysdale, I., Rueda-Flores, M., Giró, A., et al. (2015). 2015 Report Card for the Mesoamerican Reef. Healthy Reefs Initiative. Belize City.

Lansing, D. (2009). The spaces of social capital: livelihood geographies and marine conservation in the Cayos Cochinos marine protected area, Honduras. J. Lat. Am. Geogr. 8, 29-54.

Lavín, M. F., and Marinone, S. G. (2003). "An overview of the physical oceanography of the Gulf of California," in Nonlinear Processes in Geophysical Fluid Dynamics: A Tribute to the Scientific Work of Pedro Ripa, eds O. U. Velasco Fuentes, J. Sheinbaum, and J. Ochoa (Dordrecht: Springer Netherlands), 173-204. doi: 10.1007/978-94-010-0074-1_11

Lemos, M. C., Arnott, J. C., Ardoin, N. M., Baja, K., Bednarek, A. T., Dewulf, A., et al. (2018). To co-produce or not to co-produce. Nat. Sustain. 1, 722-724. doi: 10.1038/s41893-018-0191-0

Leslie, H. (2005). A synthesis of marine conservation planning approaches. Conserv. Biol. 19, 1701-1713. doi: 10.1111/j.1523-1739.2005.00268.x

Lester, S. E., Halpern, B. S., Grorud-Coveret, L., Lubchenco, J., Ruttenberg, B. I., Gaines, S. D., et al. (2009). Biological effects within no-take marine reserves: a global synthesis. Mar. Ecol. Prog. Ser. 384, 33-49.

Levin, P. S., Breslow, S. J., Harvey, C. J., Norman, K. C., Poe, M. R., Williams, G. D., et al. (2016). Conceptualization of social-ecological systems of the California current: an examination of interdisciplinary science supporting ecosystembased management. Coast. Manag. 44, 397-408. doi: 10.1080/08920753.2016. 1208036

Liu, J., Mooney, H., Hull, V., Davis, S. J., Gaskell, J., Hertel, T., et al. (2015). Systems integration for global sustainability. Science 347:1258832. doi: 10.1126/science. 1258832

Lluch-Cota, S. E., Aragón-Noriega, E. A., Arreguín-Sánchez, F., Aurioles-Gamboa, D., Jesús Bautista-Romero, J., Brusca, R. C., et al. (2007). The Gulf of California: review of ecosystem status and sustainability challenges. Prog. Oceanogr. 73, 1-26. doi: 10.1016/j.pocean.2007.01.013

Lockwood, M. (2010). Good governance for terrestrial protected areas: a framework, principles and performance outcomes. J. Environ. Manage. 91, 754-766. doi: 10.1016/j.jenvman.2009.10.005

Lockwood, M., Davidson, J., Curtis, A., Stratford, E., and Griffith, R. (2010). Governance principles for natural resource management. Soc. Nat. Resour. 23, 986-1001. doi: 10.1080/08941920802178214

Long, R. D., Charles, A., and Stephenson, R. L. (2015). Key principles of marine ecosystem-based management. Mar. Policy 57, 53-60. doi: 10.1016/j.marpol. 2015.01.013

López, G. (2021). Los Refugios Pesqueros: Una Herramienta para el Futuro de la Pesca. Causa Nat. Available online at: http://mydomain.com/pagina (accessed April 29, 2021).

Lorenzo, M. D., Guidetti, P., Franco, A. D., Calò, A., and Claudet, J. (2020). Assessing spillover from marine protected areas and its drivers: a metaanalytical approach. Fish Fish. 21, 906-915. doi: 10.1111/faf.12469

Magris, R. A., Andrello, M., Pressey, R. L., Mouillot, D., Dalongeville, A., Jacobi, M. N., et al. (2018). Biologically representative and well-connected marine reserves enhance biodiversity persistence in conservation planning. Conserv. Lett. 11:e12439. doi: 10.1111/conl.12439

Maida, C. A., and Beck, S. (2016). Towards communities of practice in global sustainability. Anthropol. Action 23, 1-5. doi: 10.3167/aia.2016.230101

Maldonado, J. H., and del Pilar Moreno-Sánchez, R. (2014). Estimating the adaptive capacity of local communities at marine protected areas in Latin America: a practical approach. Ecol. Soc. 19:16. doi: 10.5751/ES-05962-190116

Mancha-Cisneros, M. M., Lasch-Thaler, C., Vázquez-Vera, L., Suárez-Castillo, A. N., Walther-Mendoza, M., Espinosa-Romero, M. J., et al. (2018a). Recovery Zones in the Gulf of California, Mexico: Socioeconomic and Governance 
Considerations. Case Study for the Loreto-La Paz Corridor. La Paz, MX: The Nature Conservancy/Comunidad y Biodiversidad A.C.

Mancha-Cisneros, M. M., Lasch-Thaler, C., Vázquez-Vera, L., Suárez-Castillo, A. N., Walther-Mendoza, M., Espinosa-Romero, M. J., et al. (2018b). Recovery Zones in the Gulf of California, Mexico: Socio-Economic and Governance Considerations. Case Study for the Midriff Islands Region. La Paz, MX: The Nature Conservancy/Comunidad y Biodiversidad A.C.

Mancha-Cisneros, M. M., Lasch-Thaler, C., Vázquez-Vera, L., Suárez-Castillo, A. N., Walther-Mendoza, M., Espinosa-Romero, M. J., et al. (2018c). Recovery Zones of the Gulf of California, Mexico: Socio-Economic and Governance Considerations. Case Study for the Peñasco-Lobos Corridor. La Paz, MX: The Nature Conservancy/Comunidad y Biodiversidad A.C.

Mangubhai, S., Wilson, J. R., Rumetna, L., Maturbongs, Y., and Purwanto (2015). Explicitly incorporating socioeconomic criteria and data into marine protected area zoning. Ocean Coast. Manag. 116, 523-529. doi: 10.1016/j.ocecoaman. 2015.08.018

Margules, C. R., and Pressey, R. L. (2000). Systematic conservation planning. Nature 405, 243-253. doi: 10.1038/35012251

Marques, A. S., Ramos, T. B., Caeiro, S., and Costa, M. H. (2011). Adaptiveparticipative sustainability indicators in marine protected areas: design and communication. Ocean Coast. Manag. 72, 36-45. doi: 10.1016/j.ocecoaman. 2011.07.007

Marshall, G. (2007). Nesting, subsidiarity, and community-based environmental governance beyond the local scale. Int. J. Commons 2, 75-97.

Maxwell, S. L., Cazalis, V., Dudley, N., Hoffmann, M., Rodrigues, A. S. L., Stolton, S., et al. (2020). Area-based conservation in the twenty-first century. Nature 586, 217-227. doi: 10.1038/s41586-020-2773-z

McCay, B. J., Micheli, F., Ponce-Díaz, G., Murray, G., Shester, G., Ramirez-Sanchez, S., et al. (2014). Cooperatives, concessions, and co-management on the Pacific coast of Mexico. Mar. Policy 44, 49-59. doi: 10.1016/j.marpol.2013.08.001

McDermott, M., Mahanty, S., and Schreckenberg, K. (2013). Examining equity: a multidimensional framework for assessing equity in payments for ecosystem services. Environ. Sci. Policy 33, 416-427. doi: 10.1016/j.envsci.2012.10.006

Micheli, F., Saenz-Arroyo, A., Greenley, A., Vazquez, L., Montes, J. A. E., Rossetto, M., et al. (2012). Evidence that marine reserves enhance resilience to climatic impacts. PLoS One 7:e40832. doi: 10.1371/journal.pone.0040832

Mitchell, R. E., and Leach, B. (2019). Knowledge coproduction in environmental impact assessment: lessons from the mining industry in Panama. Environ. Policy Gov. 29, 87-96. doi: 10.1002/eet.1832

Morrison, T. H. (2017). Evolving polycentric governance of the Great Barrier Reef. Proc. Natl. Acad. Sci. U.S.A. 114, E3013-E3021. doi: 10.1073/pnas.1620830114

Morzaria-Luna, H., Cruz-Piñón, G., Brusca, R. C., López-Ortiz, A. M., MorenoBáez, M., Reyes-Bonilla, H., et al. (2018). Biodiversity hotspots are not congruent with conservation areas in the Gulf of California. Biodivers. Conserv. 27, 3819-3842. doi: 10.1007/s10531-018-1631-x

Morzaria-Luna, H. N., Turk-Boyer, P., Hernández, J. M. D., Polanco-Mizquez, E., Downton-Hoffmann, C., Cruz-Piñón, G., et al. (2020a). Fisheries management tools to support coastal and marine spatial planning: a case study from the Northern Gulf of California, Mexico. MethodsX 7:101108. doi: 10.1016/j.mex. 2020.101108

Morzaria-Luna, H. N., Turk-Boyer, P., Polanco-Mizquez, E. I., DowntonHoffmann, C., Cruz-Piñón, G., Carrillo-Lammens, T., et al. (2020b). Coastal and marine spatial planning in the northern Gulf of California, Mexico: consolidating stewardship, property rights, and enforcement for ecosystembased fisheries management. Ocean Coast. Manag. 197:105316. doi: 10.1016/ j.ocecoaman.2020.105316

Munguia-Vega, A. (2018). Adaptación de Principios Biofísicos para el Diseño de Zonas de Recuperación en la Región Pacífico de la Península de Baja California COBI y TNC: La Paz, México.

Munguia-Vega, A., Green, A. L., Suarez-Castillo, A. N., Espinosa-Romero, M. J., Aburto-Oropeza, O., Cisneros-Montemayor, A. M., et al. (2018a). Ecological guidelines for designing networks of marine reserves in the unique biophysical environment of the Gulf of California. Rev. Fish Biol. Fish. 28, 749-776. doi: 10.1007/s11160-018-9529-y

Munguia-Vega, A., Torres-Origel, J. F., and Vazquez-Vera, L. (2018b). Identificación y Evaluación de Sitios para el Manejo Pesquero en el Golfo de California. La Paz, MX: The Nature Conservancy.
Noble, M. M., Harasti, D., Pittock, J., and Doran, B. (2019). Understanding the spatial diversity of social uses, dynamics, and conflicts in marine spatial planning. J. Environ. Manag. 246, 929-940. doi: 10.1016/j.jenvman.2019.06.048

Norström, A. V., Cvitanovic, C., Löf, M. F., West, S., Wyborn, C., Balvanera, P., et al. (2020). Principles for knowledge co-production in sustainability research. Nat. Sustain. 3, 182-190. doi: 10.1038/s41893-019-0448-2

Olson, D. M., and Dinerstein, E. (2002). The global 200: priority ecoregions for global conservation. Ann. Mo. Bot. Gard. 89, 199-224. doi: 10.2307/3298564

Ostrom, E. (1999). Coping with tragedies of the commons. Annu. Rev. Polit. Sci. 2, 493-535. doi: 10.1146/annurev.polisci.2.1.493

Ostrom, E. (2009). A general framework for analyzing sustainability of socialecological systems. Science 325, 419-422. doi: 10.1126/science.1172133

Ostrom, E. (2010). Polycentric systems for coping with collective action and global environmental change. Glob. Environ. Change 20, 550-557. doi: 10.1016/j. gloenvcha.2010.07.004

Páez-Osuna, F., Álvarez-Borrego, S., Ruiz-Fernández, A. C., García-Hernández, J., Jara-Marini, M. E., Bergés-Tiznado, M. E., et al. (2017). Environmental status of the Gulf of California: a pollution review. Earth Sci. Rev. 166, 181-205. doi: 10.1016/j.earscirev.2017.01.014

Palacios-Abrantes, J., Cisneros-Montemayor, A. M., Cisneros-Mata, M. A., Rodríguez, L., Arreguín-Sánchez, F., Aguilar, V., et al. (2019). A metadata approach to evaluate the state of ocean knowledge: strengths, limitations, and application to Mexico. PLoS One 14:e0216723. doi: 10.1371/journal.pone. 0216723

Pascual, U., Phelps, J., Garmendia, E., Brown, K., Corbera, E., Martin, A., et al. (2014). Social equity matters in payments for ecosystem services. Bioscience 64, 1027-1036. doi: 10.1093/biosci/biu146

Pinsky, M. L., Selden, R. L., and Kitchel, Z. J. (2020). Climate-driven shifts in marine species ranges: scaling from organisms to communities. Annu. Rev. Mar. Sci. 12, 153-179. doi: 10.1146/annurev-marine-010419-010916

Poe, M. R., Norman, K. C., and Levin, P. S. (2014). cultural dimensions of socioecological systems: key connections and guiding principles for conservation in coastal environments: cultural dimensions of coastal conservation. Conserv. Lett. 7, 166-175. doi: 10.1111/conl.12068

Pomeroy, R. S., Parks, J. E., and Watson, L. M. (2004). How is Your MPA Doing?: A Guidebook of Natural and Social Indicators for Evaluating Marine Protected Area Management Effectiveness. Gland: IUCN.

Punt, A. E., and Smith, A. D. M. (2001). "The gospel of maximum sustainable yield in fisheries management: birth, crucifixion and reincarnation," in Conservation of Exploited Species, eds J. D. Reynolds, G. M. Mace, K. H. Redford, and J. G. Robinson (Cambridge: Cambridge University Press), 41-66.

Quintana Roo Gobierno del Estado (2020). Diversificacion y Desarrollo del Turismo. Available online at: https://qroo.gob.mx/eje-1-desarrollo-ydiversificacion-economica-con-oportunidades-para-todos/diversificacion-y (accessed November 19, 2020).

Ramírez-Valdez, A., Aburto-Oropeza, O., Arafeh Dalmau, N., Beas-Luna, R., Caselle, J. E., Castorani, M. C. N., et al. (2017). Mexico-California Bi-National Initiative of Kelp Forest Ecosystems and Fisheries. Available online at: https: //escholarship.org/uc/item/8sp8j4xs (accessed October 22, 2020).

Reed, M. S. (2008). Stakeholder participation for environmental management: a literature review. Biol. Conserv. 141, 2417-2431. doi: 10.1016/j.biocon.2008.07. 014

Reed, M. S., Fraser, E. D. G., and Dougill, A. J. (2006). An adaptive learning process for developing and applying sustainability indicators with local communities. Ecol. Econ. 59, 406-418. doi: 10.1016/j.ecolecon.2005.11.008

Reed, M. S., Graves, A., Dandy, N., Posthumus, H., Hubacek, K., Morris, J., et al. (2009). Who's in and why? A typology of stakeholder analysis methods for natural resource management. J. Environ. Manag. 90, 1933-1949. doi: 10.1016/ j.jenvman.2009.01.001

Roberts, C. M., McClean, C. J., Veron, J. E. N., Hawkins, J. P., Allen, G. R., McAllister, D. E., et al. (2002). Marine biodiversity hotspots and conservation priorities for tropical reefs. Science 295, 1280-1284. doi: 10.1126/science. 1067728

Roberts, C. M., O’Leary, B. C., McCauley, D. J., Cury, P. M., Duarte, C. M., Lubchenco, J., et al. (2017). Marine reserves can mitigate and promote adaptation to climate change. Proc. Natl. Acad. Sci. U.S.A. 114, 6167-6175. doi: $10.1073 /$ pnas. 1701262114 
Rodríguez-Rodríguez, D., Sciberras, M., Foster, N. L., and Attrill, M. J. (2015). Status of management effort in 153 marine protected areas across the English channel. Mar. Pollut. Bull. 94, 168-175. doi: 10.1016/j.marpolbul.2015.02.036

Rosales, R. M. P. (2018). SEAT: measuring socio-economic benefits of marine protected areas. Mar. Policy 92, 120-130. doi: 10.1016/j.marpol.2018.02.026

Ruiz-Frau, A., Kaiser, M. J., Edwards-Jones, G., Klein, C. J., Segan, D., and Possingham, H. P. (2015). Balancing extractive and non-extractive uses in marine conservation plans. Mar. Policy 52, 11-18. doi: 10.1016/j.marpol.2014. 10.017

Saarman, E., Gleason, M., Ugoretz, J., Airamé, S., Carr, M., Fox, E., et al. (2013). The role of science in supporting marine protected area network planning and design in California. Ocean Coast. Manag. 74, 45-56. doi: 10.1016/j.ocecoaman. 2012.08.021

Sala, E., and Giakoumi, S. (2018). No-take marine reserves are the most effective protected areas in the ocean. ICES J. Mar. Sci. 75, 1166-1168. doi: 10.1093/ icesjms/fsx059

Sánchez-Ibarra, C. S., Bermúdez-García, D. M., Bezaury-Creel, J., LaschThaler, C. L., Rodríguez-Dowdell, N., Cárdenas-Torres, N., et al. (2013). Plan de Acción para la Conservación y Aprovechamiento Sustentable de la Biodiversidad Terrestre y Marina de la Región Golfo de California y Pacífico Sudcaliforniano. Mexico, CDMX: Comisión Nacional de Áreas Naturales Protegidas (CONANP), The Nature Conservancy (TNC), Fondo Mexicano para la Conserva- ción de la Naturaleza.

Sayer, J., Sunderland, T., Ghazoul, J., Pfund, J.-L., Sheil, D., Meijaard, E., et al. (2013). Ten principles for a landscape approach to reconciling agriculture, conservation, and other competing land uses. Proc. Natl. Acad. Sci. U.S.A. 110, 8349-8356. doi: 10.1073/pnas.1210595110

Schiel, D. R., and Foster, M. S. (2015). The Biology and Ecology of Giant Kelp Forests. Oakland, CA: Univ of California Press.

SEGOB (2019). Proyecto de Modificación a la Norma Oficial Mexicana NOM-049-SAG/PESC-2014, Que Determina el Procedimiento para Establecer Zonas de Refugio para los Recursos Pesqueros en Aguas de Jurisdicción Federal de los Estados Unidos Mexicanos. Available online at: https://dof.gob.mx/nota_detalle.php?codigo=5579617\&fecha=22/11/2019\#: $\sim\{\}:$ text=PROYECTO\%20de\%20Modificación\%20a\%20la,de\%20los\% 20Estados\%20Unidos\%20Mexicanos (accessed June 25, 2021).

Stephenson, R. L., Benson, A. J., Brooks, K., Charles, A., Degnbol, P., Dichmont, C. M., et al. (2017). Practical steps toward integrating economic, social and institutional elements in fisheries policy and management. ICES J. Mar. Sci. 74, 1981-1989. doi: 10.1093/icesjms/fsx057

Stephenson, R. L., Wiber, M., Paul, S., Angel, E., Benson, A., Charles, A., et al. (2018). Integrating diverse objectives for sustainable fisheries in Canada. Can. J. Fish. Aquat. Sci. 76, 480-496. doi: 10.1139/cjfas-2017-0345

Sterling, E. J., Filardi, C., Toomey, A., Sigouin, A., Betley, E., Gazit, N., et al. (2017). Biocultural approaches to well-being and sustainability indicators across scales. Nat. Ecol. Evol. 1, 1798-1806. doi: 10.1038/s41559-017-0349-6

Tengö, M., Brondizio, E. S., Elmqvist, T., Malmer, P., and Spierenburg, M. (2014). Connecting diverse knowledge systems for enhanced ecosystem governance: the multiple evidence base approach. AMBIO 43, 579-591. doi: 10.1007/ s13280-014-0501-3

Tittensor, D. P., Beger, M., Boerder, K., Boyce, D. G., Cavanagh, R. D., CosandeyGodin, A., et al. (2019). Integrating climate adaptation and biodiversity conservation in the global ocean. Sci. Adv. 5:eaay9969. doi: 10.1126/sciadv. aay 9969

Trisos, C. H., Merow, C., and Pigot, A. L. (2020). The projected timing of abrupt ecological disruption from climate change. Nature 580, 496-501. doi: 10.1038/ s41586-020-2189-9

Tschakert, P., and Dietrich, K. (2010). Anticipatory learning for climate change adaptation and resilience. Ecol. Soc. 15:11. doi: 10.1007/s13280-016-0830-5
Turnbull, J. W., Shah Esmaeili, Y., Clark, G. F., Figueira, W. F., Johnston, E. L., and Ferrari, R. (2018). Key drivers of effectiveness in small marine protected areas. Biodivers. Conserv. 27, 2217-2242. doi: 10.1007/s10531-0181532-Z

Ulloa, R., Torre, J., Bourillon, L., Gonder, A., and Alcantar, N. (2006). Planeacion para la Conservacion Marina: Golfo de California y Costa Occidental de Baja California Sur. Guaymas, MX: Comunidad y Biodiversidad, A.C.

Uribe, P., Torre, J., Moguel, S., Bourillón, L., and Sáenz, A. (2010). Implementación de Reservas Marinas en México. México, MX: Centro Mexicano de Derecho Ambiental (CEMDA) Comunidad y Biodiversidad (COBI).

Ward, T. J., Vanderklift, M. A., Nicholls, A. O., and Kenchington, R. A. (1999). Selecting marine reserves using habitats and species assemblages as surrogates for biological diversity. Ecol. Appl. 9, 691-698.

Weigel, J.-Y., Mannle, K. O., Bennett, N. J., Carter, E., Westlund, L., Burgener, V., et al. (2014). Marine protected areas and fisheries: bridging the divide. Aquat. Conserv. Mar. Freshw. Ecosyst. 24, 199-215. doi: 10.1002/aq c. 2514

Westley, F., Olsson, P., Folke, C., Homer-Dixon, T., Vredenburg, H., Loorbach, D., et al. (2011). Tipping toward sustainability: emerging pathways of transformation. AMBIO 40, 762-780. doi: 10.1007/s13280-011-0186-9

Wilson, K. L., Tittensor, D. P., Worm, B., and Lotze, H. K. (2020). Incorporating climate change adaptation into marine protected area planning. Glob. Change Biol. 26, 3251-3267. doi: 10.1111/gcb.15094

Wyborn, C. (2015). Cross-scale linkages in connectivity conservation: adaptive governance challenges in spatially distributed networks. Environ. Policy Gov. 25, 1-15. doi: 10.1002/eet.1657

Wyborn, C., Datta, A., Montana, J., Ryan, M., Leith, P., Chaffin, B., et al. (2019). Co-producing sustainability: reordering the governance of science, policy, and practice. Annu. Rev. Environ. Resour. 44, 319-346. doi: 10.1146/annurevenviron-101718-033103

Young, J. C., Searle, K., Butler, A., Simmons, P., Watt, A. D., and Jordan, A. (2016). The role of trust in the resolution of conservation conflicts. Biol. Conserv. 195, 196-202. doi: 10.1016/j.biocon.2015.12.030

Zafra-Calvo, N., Pascual, U., Brockington, D., Coolsaet, B., Cortes-Vazquez, J. A., Gross-Camp, N., et al. (2017). Towards an indicator system to assess equitable management in protected areas. Biol. Conserv. 211(Pt A), 134-141. doi: 10. 1016/j.biocon.2017.05.014

Conflict of Interest: The authors declare that the research was conducted in the absence of any commercial or financial relationships that could be construed as a potential conflict of interest.

Publisher's Note: All claims expressed in this article are solely those of the authors and do not necessarily represent those of their affiliated organizations, or those of the publisher, the editors and the reviewers. Any product that may be evaluated in this article, or claim that may be made by its manufacturer, is not guaranteed or endorsed by the publisher.

Copyright (c) 2021 Précoma-de la Mora, Bennett, Fulton, Munguia-Vega, LaschThaler, Walther-Mendoza, Zepeda-Domínguez, Finkbeiner, Green, Suárez, Weaver, Figueroa Carranza, Vega Velázquez, Zepeda, Montes, Fuentes Montalvo, Micheli, Reyes-Bonilla, Chollett, Lopez-Ercilla, Torres Origel, Vázquez-Vera, García-Rivas, Mancha-Cisneros, Espinosa-Romero, Martín Ruíz, Arafeh-Dalmau, GonzálezCuellar, Huchim and Rodríguez Van Dyck. This is an open-access article distributed under the terms of the Creative Commons Attribution License (CC BY). The use, distribution or reproduction in other forums is permitted, provided the original author(s) and the copyright owner(s) are credited and that the original publication in this journal is cited, in accordance with accepted academic practice. No use, distribution or reproduction is permitted which does not comply with these terms. 